\title{
Controls on denudation along the East Australian continental margin
}

\author{
A.T. Codilean ${ }^{(1,2)^{*}}$, R.-H. Fülöp ${ }^{(1,3)}$, H. Munack ${ }^{(1,2)}$, K.M. Wilcken $^{(3)}$, T.J. Cohen $^{(1,2)}$, D.H. Rood ${ }^{(4)}$, \\ D. Fink ${ }^{(3)}$, R. Bartley ${ }^{(5)}$, J. Croke ${ }^{(6)}$, L.K. Fifield ${ }^{(7)}$
}

(1) School or Earth, Atmospheric and Life Sciences, University of Wollongong, Wollongong, NSW 2522, Australia

(2) ARC Centre of Excellence for Australian Biodiversity and Heritage (CABAH), University of Wollongong, Wollongong, NSW 2522, Australia

(3) Australia's Nuclear Science and Technology Organisation (ANSTO), Lucas Heights, NSW 2234, Australia

(4) Department of Earth Science and Engineering, Imperial College London, London SW7 2AZ, UK

(5) CSIRO Land and Water, GPO Box 2583, Brisbane, QLD 4001, Australia

(6) School of Geography, University College Dublin, Dublin 4, Ireland

(7) Research School of Physics, The Australian National University, ACT 2601, Australia

* Corresponding author: codilean@uow.edu.au; +61242213426

\section{Abstract}

We report a comprehensive inventory of ${ }^{10} \mathrm{Be}$-based basin-wide denudation rates $(n=160)$ and ${ }^{26} \mathrm{Al} /{ }^{10} \mathrm{Be}$ ratios ( $n=67$ ) from 48 drainage basins along a 3,000 $\mathrm{km}$ stretch of the East Australian passive continental margin. We provide data from both basins draining east of the continental divide $(n=37)$ and discharging into the Tasman and Coral Seas, and from basins draining to the west as part of the larger Murray-Darling and Lake Eyre river systems $(n=11) .{ }^{10}$ Be-derived denudation rates in mainstem samples from east-draining basins range between $7.7 \pm 1.9$ ( $\pm 1 \sigma$; Mary) and $54.6 \pm 13.7 \mathrm{~mm} \mathrm{kyr}^{-1}$ (North Johnstone). Denudation rates in tributary samples range between $3.0 \pm 0.7$ (Burdekin) and $70.2 \pm 18.9 \mathrm{~mm} \mathrm{kyr}^{-1}$ (Liverpool). For west-draining basins, denudation rates are overall lower and with a more restricted range of $4.8 \pm 1.2$ (Barcoo) to $15.4 \pm 3.6 \mathrm{~mm} \mathrm{kyr}^{-1}$ (Maranoa) in mainstem samples, and between $4.4 \pm 1.0$ (Murrumbidgee) and $38.5 \pm 7.8 \mathrm{~mm} \mathrm{kyr}^{-1}$ (Murray) in tributary samples. East Australian denudation rates (median $=14.5 \mathrm{~mm} \mathrm{kyr}^{-1}$ ) are similar to those found in other postorogenic landscapes (global median $=12.4 \mathrm{~mm} \mathrm{kyr}^{-1}$ ) and the 
medians of the top $10 \%$ denudation rates recorded here $\left(46.5 \mathrm{~mm} \mathrm{kyr}^{-1}\right)$ and in other passive margin settings are also similar, despite differences in topography and precipitation. These median denudation rate values are close to the $95^{\text {th }}$ percentile denudation rate for all tectonically passive basins $\left(\approx 53 \mathrm{~mm} \mathrm{kyr}^{-1}\right)$ and are very similar to the global silicate weathering speed limit $\left(\approx 58 \mathrm{~mm} \mathrm{kyr}^{-1}\right)$ calculated as the $95^{\text {th }}$ percentile of global soil weathering rates. The above suggests that in post-orogenic terrain, the overall rates of topographic decay have a 'speed limit' that is imposed by the rate at which rock is converted to soil by chemical weathering. Denudation rates along the East Australian margin correlate with topographic metrics at both the mainstem basin scale and at the smaller tributary basin scale suggesting that topography exerts the main control on rates of landscape lowering in this setting. An important link between denudation rate and rainfall is also inferred: the highest mainstem ${ }^{10} \mathrm{Be}$ denudation rates all occur in basins which also have the highest rainfall amounts and there is a strong correlation between the distance knickpoints have travelled upstream from the river mouth and basin area - a proxy for discharge and so to some extent also rainfall. On both sides of the divide, in all but a few of the samples, ${ }^{26} \mathrm{Al} /{ }^{10} \mathrm{Be}$ ratios are consistently lower than what is expected in a setting where sediments experience a simple and continuous exposure history. East of the continental divide, the lowest ${ }^{26} \mathrm{Al} /{ }^{10} \mathrm{Be}$ ratios are found in basins that also experience increased flood variability. We posit that there is a causal link between the hydrological variability that characterises the coastal rivers of eastern Australia and the observed non-steady state ${ }^{26} \mathrm{Al} /{ }^{10} \mathrm{Be}$ ratios: the periodic stripping of vertically accreted floodplains by large floods means that deeper and potentially older material is periodically incorporated into the sediment mix transported by the modern river.

Keywords: Australia; passive continental margin; Great Dividing Range; denudation; cosmogenic ${ }^{10} \mathrm{Be}$; cosmogenic ${ }^{26} \mathrm{Al} /{ }^{10} \mathrm{Be}$;

\section{Introduction}

60 The uplift and erosion of mountain ranges is thought to regulate global climate over millionyear timescales [Raymo \& Ruddiman, 1992] while also responding to climate forcing itself [Molnar \& England, 1990; Whipple, 2009]. It remains unclear whether mountain uplift drives climate change, or vice versa, and the key role that the erosion of mountains plays in the 
global climate system is intensely debated [Zhang et al., 2001; Galy et al., 2007; Willenbring \& von Blanckenburg, 2010; Finnegan et al., 2014; Herman et al., 2013; Larsen et al., 2014; Schildgen et al., 2018]. While research explicitly on the links between tectonics, climate, and erosion has largely focused on tectonically active compressional orogens [e.g., Willett, 1999; Montgomery et al., 2001; Willett \& Brandon, 2002; Dadson et al., 2003], high-elevation passive continental margins such as those found in southern Africa, western India, eastern North America, and eastern Australia, can provide important insights. First, passive continental margins are major, first-order topographic features of the Earth's surface that, although tectonically quiescent at present, can be clearly related to plate tectonic processes and setting [Bishop, 2007 and references therein]. Second, given their expanse, the formation and long-term evolution of high-elevation passive continental margins has implications on the large-scale spatial and temporal rearrangement of mass at the Earth's surface (via denudation and sediment flux) and so exerts a first-order control on large-scale patterns of tectonic and isostatic uplift [Gilchrist \& Summerfield, 1990; Gilchrist et al., 1994; Tucker \& Slingerland, 1994]. The latter has implications on timescales of topographic decay [Baldwin et al., 2003; Braun et al., 2014] and therefore on tectonics-topography-erosion couplings. The denudational history of high-elevation passive continental margins also has bearing on the formation of major hydrocarbon fields in these settings [Mann et al., 2003], and so an understanding of post-breakup passive margin evolution is important to the global economy.

The long-term evolution of the East Australian continental margin was the subject of research in the mid-19th century by the luminaries of Charles Darwin (1890) during his visit to Australia on The Beagle in 1836, who saw the gorges as the result of the marine erosion of cliffs, and James Dana (1850) who was the first to describe their correct formation as due to intense fluvial activity. It was a landscape seen subsequently, however, largely in Davisian terms as being one of multiple cycles of peneplanation analogous to then current interpretations of North American uplands [e.g., Andrews, 1903]. While a few proposed from various lines of evidence a much older landscape [e.g., Craft, 1932; 1933] their ideas did not prevail and as late as the mid $20^{\text {th }}$ century it was still believed that the uplift of this margin was as late as Miocene-Pliocene with gorge cutting of the plateaus associated with intense episodes of Quaternary fluvial activity [e.g., King, 1959; Browne, 1969]. Much of the 
current insight into the evolution and antiquity of the East Australian highland belt came in the south-eastern sector with the dating of widespread Cenozoic plateau and valley basalt flows [e.g., Wellman \& McDougall, 1974; Wellman, 1979; Bishop \& Young, 1980; Ollier, 1982; Young, 1983; Bishop, 1985; Lambeck \& Stephenson, 1986; Lister \& Etheridge, 1989; Young \& McDougall, 1993; Nott et al., 1996; Bishop \& Goldrick, 2010]. Data obtained from these studies along with results from surface process models [e.g., Gilchrist \& Summerfield, 1994; Kooi \& Beaumont, 1994; van der Beek \& Braun, 1998, 1999; van der Beek et al., 2001; Braun \& van der Beek, 2004; see also Braun, 2018] and those from studies employing lowtemperature thermochronometers such as apatite fission track and apatite (U-Th)/He [e.g., Dumitru et al., 1991; Persano et al., 2002; 2005], have permitted the testing of conceptual models proposed for the post-breakup evolution of high-elevation passive continental margins, and have provided important constrains on the rates and style of landscape denudation in these settings. Notwithstanding, rates of landscape denudation obtained from the study of Cenozoic basalts [e.g., Nott et al., 1996] are spatially restricted, and thermochronometric methods lack the sensitivity required to resolve denudation rates over the spatial and temporal scales that are relevant to geomorphology.

Cosmogenic radionuclides - especially in situ produced ${ }^{10} \mathrm{Be}$ - have proven to be the best suited technique for studying the erosion of Earth's continental topography over millennial timescales. Indeed, ${ }^{10} \mathrm{Be}$-based denudation rates have now been determined in thousands of river basins [Codilean et al., 2018], providing us with a substantial inventory of erosion rate estimates from several high-elevation passive continental margins, including southeast Brazil [e.g., Barreto et al., 2013; Gonzalez et al., 2016; Salgado et al., 2016], south and southeast Africa [Bierman and Caffee 2001; Codilean et al., 2008, 2014; Scharf et al., 2013; Bierman et al., 2014], western India [Mandal et al., 2015], Sri Lanka [e.g., von Blanckenburg et al., 2004; Vanacker et al., 2007a], and eastern North America [e.g., Miller et al., 2013;

120 Reusser et al., 2015]. Along the East Australian margin, studies employing ${ }^{10} \mathrm{Be}$ and with an explicit focus on denudation along the Great Escarpment have been spatially restricted to a few basins in the southern sector of the margin (e.g., Bega: Heimsath et al. [2000, 2001, 2006], Godard et al. [2019]; Blue Mountains: Tomkins et al. [2007]; Macleay: Weissel \& Seidl [1998]). In the northern sector of the East Australian margin - where both elevations and relief are more subdued and the continental divide is farther inland - studies employing 
${ }^{10} \mathrm{Be}$ have focused on constraining sediment sources and sediment yields (both contemporary and longer-term) to the Great Barrier Reef, with questions relevant to the long-term evolution of the margin being secondary [e.g., Nichols et al., 2014; Croke et al., 2015; Mariotti et al., 2020].
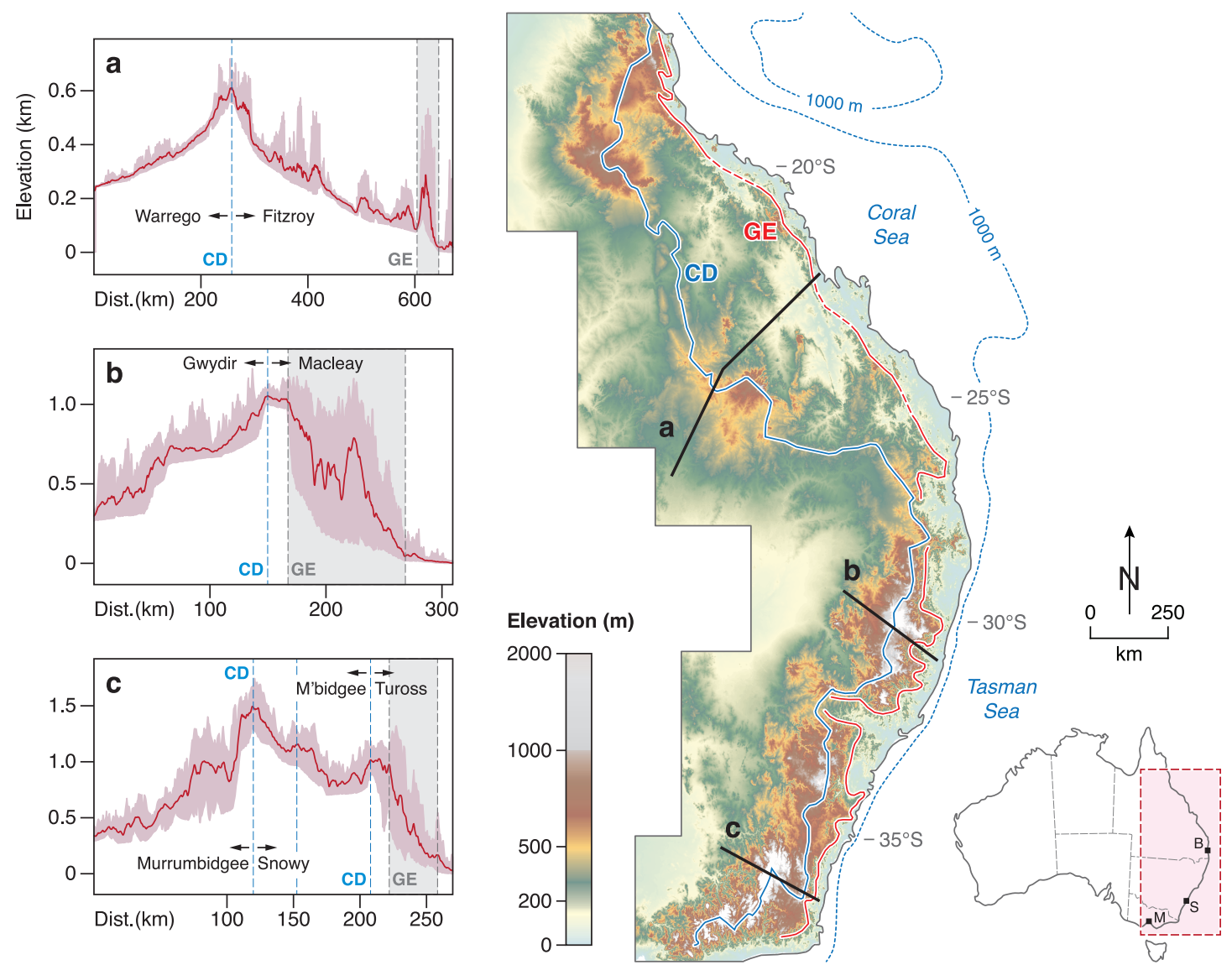

Figure 1: Topography of the East Australian margin. Swath profiles were produced over a width of $25 \mathrm{~km}$ with red lines showing average and envelopes showing minimum and maximum elevation values. Dotted blue line depicts the $1000 \mathrm{~m}$ isobath and is shown here to indicate the width of the continental shelf. CD - Continental Divide; GE - Great Escarpment. Grey band on swath profiles indicates the escarpment zone - note how this zone is narrow in the northern sector of the margin and becomes wider in the southern sector where the escarpment is more sinuous and heavily dissected by rivers. Inset map shows the location of major cities: $M$-Melbourne, S-Sydney, B-Brisbane.

130 The morphology of the East Australian passive margin is that of the less common arch-type margin [cf. Matmon et al., 2002]: along most of its length the major highland drainage divide is situated inland (i.e., westward) of the crest of the escarpment (Figure 1). Thus, rivers draining the escarpment with headwater plateau regions will have larger drainage 
areas than their counterparts on the more common shoulder-type margins (where the drainage divide coincides with the escarpment lip). Such arch-type margin basins are inferred to have higher discharges, and greater stream power that will promote knickpoint retreat and faster embayment of the escarpment [e.g., Nott et al., 1996; Weissel \& Seidl, 1998]. The latter characteristics make the East Australian margin particularly well-suited to testing conceptual models of the post-breakup evolution of passive margins (i.e., with respect to discriminating between escarpment retreat and excavation in place by downwearing; see: Gallagher et al. [1998]), and also well-suited to exploring transient landscape dynamics and issues related to the protracted decay of topography in postorogenic terrains.

In this study we provide a comprehensive inventory of ${ }^{10}$ Be-based denudation rates $(n=160)$ and ${ }^{26} \mathrm{Al} /{ }^{10} \mathrm{Be}$ ratios ( $\mathrm{n}=67$ ) from rivers draining Australia's Great Dividing Range (Figure 1 ) between the Mitchell River in southeast Victoria ( $\approx 38^{\circ} \mathrm{S}$ latitude) and the Daintree River in north Queensland ( $\approx 16^{\circ} \mathrm{S}$ latitude). We compiled published data from the OCTOPUS database [Codilean et al., 2018] and more recent studies [Portenga et al., 2016; Godard et al., 2019; Eccleshall, 2019; Fülöp et al., 2020; Mariotti et al., 2021], and present new ${ }^{10} \mathrm{Be}$ and ${ }^{26} \mathrm{Al}$ data from a further 40 and 47 basins, respectively. Our aim is to identify major first order controls on ${ }^{10} \mathrm{Be}$-derived denudation rates along the length of the margin, explore east-west differences in rates of denudation, and place these rates in a global context by comparing to other high-elevation passive continental margins. We also explore sediment residence times and the potential influence of the flood variability that characterises the coastal rivers of eastern Australia on the ${ }^{26} \mathrm{Al} /{ }^{10} \mathrm{Be}$ ratios in the sediment.

\section{Study area}

\subsection{Geomorphologic and geologic setting}

The East Australian passive continental margin formed by continental extension, rifting and break-up during the fragmentation of Gondwana in the late Mesozoic and early Cenozoic at circa 80 - 65 Ma [Weissel \& Hayes, 1977; Falvey \& Mutter, 1981; Veevers, 1984; Colwell et al., 1993]. The history of the highlands forming the East Australian margin is still unresolved; however, it is now generally accepted that highland uplift pre-dated the Cenozoic [see 
discussion in Bishop \& Goldrick, 2000]. It has been argued that the whole of the highlands should not be treated as a single morphotectonic unit that shares a common history [Bishop, 1988; Ollier \& Pain, 1996], which is a view that is supported by the marked morphological differences between the southern and northern sectors of the highlands (Figure 1) and the different plate tectonic histories of their respective margins. These morphological differences, however, make the margin interesting from a denudation / surface processes point of view and thus warrant the inclusion of basins from both southern and northern sectors in this study.

Our study area stretches about $3,000 \mathrm{~km}$ along the East Australian margin between $\approx 38^{\circ} \mathrm{S}$ and $\approx 16^{\circ} \mathrm{S}$ latitude. In the southern sector, between $\approx 38^{\circ} \mathrm{S}$ and $\approx 26^{\circ} \mathrm{S}$, the Great Dividing Range takes the form of a broad asymmetrical arch located close to the present coastline (Figure 1). Elevations rise gently from the interior to the continental drainage divide, with the latter being an area of generally low relief. The low relief continues east of the divide until the crest of the Great Escarpment, across which east-flowing rivers descend through dissected ranges to a coastal plain with relief decreasing towards the coast (Figure 1). North of $26^{\circ} \mathrm{S}$ the continental drainage divide moves further inland and the Great Dividing Range takes the form of a broader, more diffuse, and more symmetrical arch (Figure 1). In the northern sector (between $\approx 26^{\circ} \mathrm{S}$ and $\approx 16^{\circ} \mathrm{S}$ ), east-flowing rivers have generally larger drainage basins with both elevations and relief being more subdued than in the south (Figure 1). The Great Escarpment is more fragmented in the north, but as in the southern sector, follows the present coastline. Interestingly, the distinct morphologies of the two sectors are broadly mirrored by the morphology of the continental shelf - narrow in the south and broad in the north (dotted blue line in Figure 1).

The Great Dividing Range consists of uplifted Palaeozoic basement rocks belonging to the Tasman Orogen, namely granites and metasedimentary sequences of the Lachlan and New England Fold Belts and intervening Late Palaeozoic and Mesozoic sedimentary sequences such as those of the Permo-Triassic Sydney Basin - that have generally experienced only mild deformation [Coney et al., 1990; Veevers, 2006]. The western and southern edges of the highlands are covered by Mesozoic and Cenozoic sedimentary sequences - such as the Murray and Eromanga-Surat Basin sequences in the west, and the Otway and Gippsland 
Basin sequences on the Victorian coast [Veevers, 2000; Raymond et al., 2012]. Within the actual highlands there are minor but widespread occurrences of Cenozoic sedimentary deposits, and more extensive - but still minor - occurrences of Late Mesozoic and Cenozoic basaltic lavas [Wellman \& McDougall, 1974; Johnson, 1989; Raymond et al., 2012] (see Figure S1A). Overall, with the exception of the Cenozoic basalts, quartz is abundant throughout the study area.

\subsection{Climatic and hydrologic setting}

200

In terms of climate, an essentially present-day climatic regime was in operation in Australia from the beginning of the Pleistocene, however overall precipitation was higher than that of today [Martin, 2006; Fujioka \& Chappell, 2010]. Quaternary glaciation was restricted to Tasmania and small parts of the Snowy Mountains in the south of the margin [Barrows et al., 2001; 2002; Augustinus et al., 2017; Kiernan et al., 2017]. Outside these areas, in broad terms, the interglacial periods, but probably excluding the interglacial maxima, were wetter and glacial periods but probably excluding the glacial maxima, were drier, however the general trend through the Pleistocene and Holocene has been that of a gradual decrease in precipitation [Nanson et al., 1992; 2008; Kershaw \& Nanson, 1993]. In terms of current conditions, mean annual rainfall varies from $400 \mathrm{~mm}$ year $^{-1}$ in the inland regions of the

210 Fitzroy and Burdekin Rivers to greater than $3,000 \mathrm{~mm}$ year $^{-1}$ in the wetter parts of northern Queensland (Figure 2 and Figure S1B). The southern sector of the margin (south Queensland and New South Wales) typically receives mean annual rainfall of $600-1200 \mathrm{~mm}$ year $^{-1}$. Rainfall decreases away from the coast, and westwards of the continental divide mean annual rainfall decreases to $400-800 \mathrm{~mm}_{\text {year }}{ }^{-1}$, and in some basins to even below $400 \mathrm{~mm}$ year $^{-1}$ (Figure S1B). Drainage basins north of the Fitzroy River (Figure 2) are dominated by summer rainfall and tropical cyclone activity. In the middle section of the margin (between Fitzroy and Hunter; basins \#27 and \#14 respectively in Figure 2) a less intense summer precipitation dominance prevails, whereas the southern sector of the margin experiences a relatively uniform seasonal precipitation regime, although the southernmost basins (Genoa

220 - Mitchell; Figure 2) experience peak runoff in the austral winter months [Bureau of Meteorology, 2018]. 


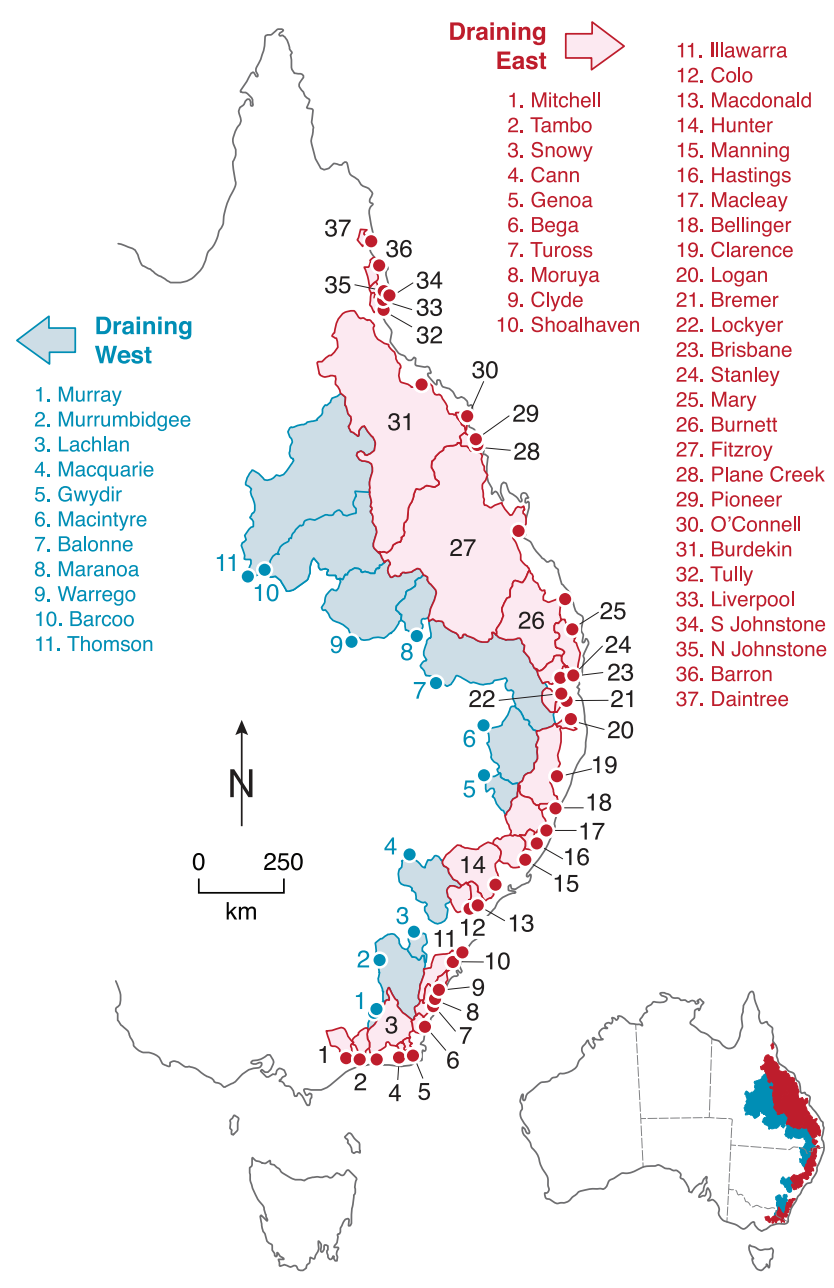

Figure 2: Distribution of east and west draining basins included in this study. The study area stretches about 3,000 km along the East Australian margin and basins range in area between $35-139,000 \mathrm{~km}^{2}$ (east) and 3,300-150,000 km² (west). See Figure 3 for map of tributary basins and Table $\mathrm{S} 1$ for further detail.

Research on comparative global hydrology [Finlayson \& McMahon, 1988] indicates that Australia (and southern Africa) are currently hydrologically distinct from the rest of the world. This is shown through a series of metrics: (1) the coefficient of variation of annual runoff and (2) the standard deviation of logarithms to base 10 of peak discharges for all basin areas - both of which are the highest in the world; (3) the ratio of the peak discharge for the $1 \%$ annual exceedance probability flood to the mean annual flood is generally higher than elsewhere; and (4) the coefficient of skewness of the log transformed annual floods is more than three times that for the rest of the world [Finlayson \& McMahon, 1988]. Such hydrological characteristics demonstrate that Australian rivers are currently generally 
characterised by high flood variability and/or steep annual series flood frequency curves. This is particularly the case for eastern Australia and such rivers have been said to be sensitive to flood-induced channel changes in their alluvial reaches [Abrahams \& Cull, 1979; Neller, 1980; Erskine, 1986]. On the east coast, this large inter-annual and overall flood variability is spatially variable [e.g., Rustomji et al., 2009] and is also superimposed on multidecadal variability (flood and drought dominated periods) modulated by the Interdecadal Pacific Oscillation - IPO [Power et al., 1999; Kiem et al., 2003].

\section{Methods}

\subsection{Sample sites}

240

We report cosmogenic radionuclide data for 48 drainage basins: 37 draining to the east and discharging into the Tasman and Coral Seas, and 11 draining to the west as part of the larger Murray-Darling and Lake Eyre river systems (Table S1, Figure 2). For all 48 basins, samples were collected from the mainstem, and for 19 basins, samples are also available from tributaries, with 11 located east of the continental divide and four to the west (Figure 3). In total, we report ${ }^{10} \mathrm{Be}$ results in 160 samples, and ${ }^{26} \mathrm{Al}$ results in 67 samples. Of the reported data, $40{ }^{10} \mathrm{Be}$ and $47{ }^{26} \mathrm{Al}$ are previously unpublished data, and the rest have been compiled from the OCTOPUS database [Codilean et al., 2018] and more recent studies, namely, Portenga et al. [2016], Godard et al. [2019], Eccleshall [2019], Fülöp et al. [2020], and Mariotti et al. [2021]. Basin areas for the mainstem samples range between 35 and 139,000 $\mathrm{km}^{2}$ for Macquarie Rivulet (IIlawarra) and Fitzroy River, respectively, draining east, and between 3,300 and 150,000 $\mathrm{km}^{2}$ for Lachlan River and Thomson River, respectively, draining west. For rivers draining east, basin areas reflect the morphology of the margin and the distance of the continental divide from the coast, i.e., smaller basins in the southern sector and larger basins in the northern sector. For the western rivers, basin areas of samples included in this analysis are dictated by the data available in the literature, however, fortuitously, areas of available basins both east and west of the divide are not dissimilar. In terms of tributary samples, there is a good geographic distribution (and also representation of basin sizes) along the length of the margin on the eastern side of the divide, whereas west of the divide, three of the four tributary basins are in the southern sector of the margin and tributary areas cover a lesser range (Figure 3). 


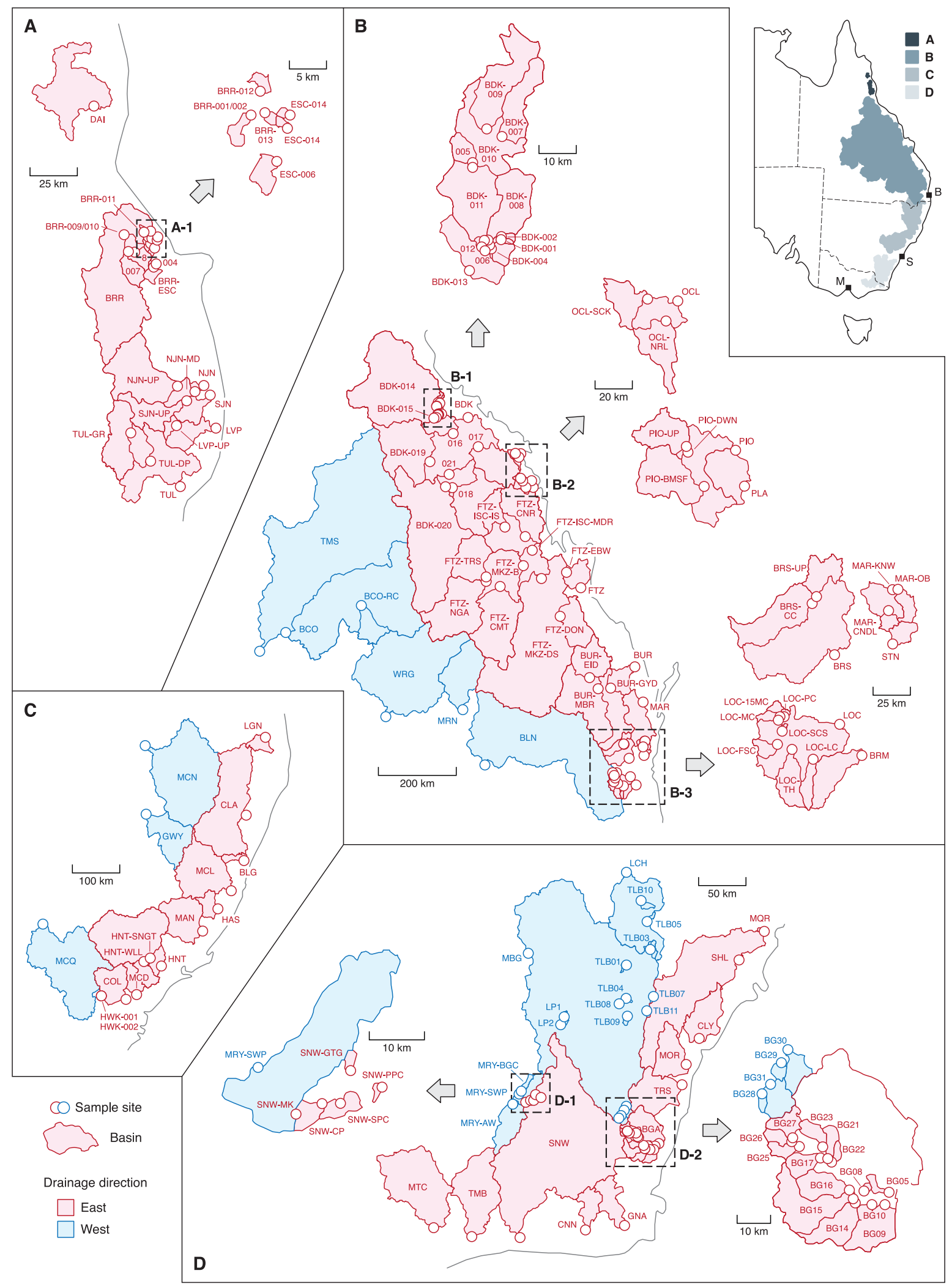

Figure 3: Distribution of sample sites and associated drainage basins. Further detail is provided in Table S1. Inset map shows the location of major cities: $M$-Melbourne, $S-$ Sydney, B-Brisbane. 


\subsection{Cosmogenic ${ }^{10} \mathrm{Be}$ and ${ }^{26} \mathrm{Al}$ analyses}

Sediment - collected as part of the new samples presented in this study - was sieved in the field to isolate the $250-500 \mu \mathrm{m}$ fraction for analysis, and quartz was purified following procedures described in Kohl and Nishiizumi [1992] using froth flotation to separate feldspars from quartz. For all but two of the samples, Be and Al were separated at the University of Wollongong following procedures described in von Blanckenburg et al. [1996] with the modification that $\mathrm{Al}$ was separated from $\mathrm{Be}$ and $\mathrm{Ti}$ using $\mathrm{pH}$ sensitive precipitation before Be cation exchange chromatography [Child et al., 2000]. Samples were spiked with $\approx 300 \mu \mathrm{g}$ of ${ }^{9} \mathrm{Be}$ from a low-level beryl carrier solution added prior to complete HF dissolution. For samples FTZ and PIO-UP, beryllium was separated at Imperial College London following procedures described in Corbett et al. [2016]. ${ }^{26} \mathrm{Al}$ measurements of the Co-QTZ-N ( $n=13)$ [Binnie et al., 2019], and CRONUS-A ( $n=5)$ and CRONUS-N ( $n=6)$ [Jull et al., 2015] laboratory intercomparison materials prepared at the University of Wollongong between 2017 and 2020 yield results in agreement with consensus values (Table 1) suggesting that our Al chemistry procedures are robust and there is no systematic loss of ${ }^{27} \mathrm{Al}$ during sample processing.

${ }^{10} \mathrm{Be} /{ }^{9} \mathrm{Be}$ and ${ }^{26} \mathrm{Al} /{ }^{27} \mathrm{Al}$ ratios for samples from east-draining basins \#1 to \#25 (Figure 2 ) and the two samples prepared at Imperial College, were measured using the 6MV SIRIUS facility at ANSTO [Wilcken et al., 2019]. The native Al concentrations of the samples ranged from 88 to $290 \mathrm{ppm}$ (median $=158 \mathrm{ppm}$ ) and were determined via ICP-OES with a precision of 3-4\% [Fujioka et al., 2015]. ${ }^{10} \mathrm{Be} /{ }^{9} \mathrm{Be}$ ratios were normalised to the $\mathrm{KN}-5-2$ and $\mathrm{KN}-5-3$ [Nishiizumi et al., 2007] standards and ${ }^{26} \mathrm{Al} /{ }^{27} \mathrm{Al}$ ratios were normalised to the $\mathrm{KN}-4-2$ [Nishiizumi, 2004] standard. Analytical uncertainties for the final ${ }^{10} \mathrm{Be}$ and ${ }^{26} \mathrm{Al}$ concentrations (atoms $\mathrm{g}^{-1}$ ) include AMS measurement uncertainties (larger of counting statistics or standard deviation of repeats and blank corrections) in quadrature with $1-2 \%$ for ${ }^{10} \mathrm{Be}$ and $2-3 \%$ for ${ }^{26} \mathrm{Al}$ standard reproducibility (depending on the individual AMS measurement conditions), $1 \%$ uncertainty in the ${ }^{9} \mathrm{Be}$ carrier concentration and $4 \%$ uncertainty in the ICP-OES AI measurements. ${ }^{26} \mathrm{Al} /{ }^{27} \mathrm{Al}$ ratios for samples from the Fitzroy River (basin \#27 in Figure 2) that correspond to the ${ }^{10} \mathrm{Be}$ data in Mariotti et al., [2021], were measured using the 14UD accelerator at the Australian National University (ANU) Heavy lon Accelerator Facility [Fifield 
et al., 2010]. The native Al concentrations in these samples ranged from 124 to 687 ppm (median $=190 \mathrm{ppm}) .{ }^{26} \mathrm{Al} /{ }^{27} \mathrm{Al}$ ratios were normalised to the $\mathrm{KN}-4-3$ [Nishiizumi, 2004] standard. Results of the ${ }^{26} \mathrm{Al}$ and ${ }^{10} \mathrm{Be}$ analyses, including measurement uncertainties and blank corrections are summarised in Tables S2 and S3.

\begin{tabular}{llll} 
Material(a) & Measured value $^{(\mathbf{b})}$ & Consensus value $^{(\mathbf{b})}$ & Reference \\
\hline Co-QTZ-N & $1.57 \pm 0.05 \times 10^{7}(n=8)^{(\mathrm{c})}$ & $1.56 \pm 0.08 \times 10^{7}(n=19)$ & Binnie et al. [2019] \\
& $1.68 \pm 0.09 \times 10^{7}(n=5)^{(\mathrm{d})}$ & & \\
CRONUS-A & $1.47 \pm 0.15 \times 10^{8}(n=5)^{(\mathrm{c})}$ & $1.43 \pm 0.07 \times 10^{8}(n=13)$ & Jull et al. [2015] \\
CRONUS-N & $1.02 \pm 0.09 \times 10^{6}(n=6)^{(\mathrm{c})}$ & $1.05 \pm 0.11 \times 10^{6}(n=10)$ & Jull et al. [2015] \\
\hline
\end{tabular}

(a) Samples were prepared at the University of Wollongong between 2017 and 2020 following procedures described in the text.

(b) Values are in atoms $\mathrm{g}^{-1}$ with uncertainties reported at $1 \sigma$.

(c) Measured using the 6MV SIRIUS facility at ANSTO.

(d) Measured at ANU.

\section{Table 1: Summary of ${ }^{26} \mathrm{Al}$ measurement results in the Co-QTZ-N, CRONUS-A, and CRONUS-N laboratory intercomparison materials.}

\subsection{Denudation rate and sediment storage duration calculations}

Denudation rates were calculated using the open-source program CAIRN v.1 [Mudd et al., 2016]. Basin-averaged nuclide production from neutrons and muons was calculated with the approximation of Braucher et al. [2011] and using a sea-level and high-latitude total production rate of 4.3 atoms $\mathrm{g}^{-1} \mathrm{yr}^{-1}$ for ${ }^{10} \mathrm{Be}$ and 31.1 atoms $\mathrm{g}^{-1} \mathrm{yr}^{-1}$ for ${ }^{26} \mathrm{Al}$ [Mudd et al., 2016]. Production rates for catchment-wide denudation rates were calculated at every grid cell of a hydrologically enforced 30 m SRTM DEM [Farr et al., 2007], using the timeindependent Lal/Stone scaling scheme [Stone, 2000]. Atmospheric pressure was calculated via interpolation from the NCEP2 reanalysis data [Compo et al., 2011]. Topographic shielding was calculated from the same DEM using the method of Codilean [2006] with $\Delta \theta=$ $8^{\circ}$ and $\Delta \phi=5^{\circ}$. For consistency, all Australian denudation rate data available in the OCTOPUS database and those from the recent publications not yet available in OCTOPUS, were recalculated using CAIRN and a $30 \mathrm{~m}$ SRTM DEM.

We calculate the duration of sediment storage in basins with both ${ }^{26} \mathrm{Al}$ and ${ }^{10} \mathrm{Be}$ data following a simple single exposure - complete burial model. This approach is similar to that

310 used in other studies [e.g., Wittmann et al., 2011; Hippe et al., 2012; Struck et al., 2018b; Fülöp et al., 2020] and involves several simplifying assumptions that cannot be validated 
and are likely not met due to spatially variable denudation rates and sediment mixing [cf., Bierman \& Steig, 1996]. The two-step model is essentially flawed in a modern fluvial setting, however, inferred values are valuable for comparison with other studies. We perform our calculations in CosmoCalc v.3.0 [Vermeesch, 2007] using the time-independent Lal/Stone scaling factors [Stone, 2000], the neutron and muon production approximation of Braucher et al. [2011], and default values for all other parameters. We reference our ${ }^{26} \mathrm{Al} /{ }^{10} \mathrm{Be}$ ratios to the consensus ${ }^{26} \mathrm{Al} /{ }^{10} \mathrm{Be}$ production rate ratio of 6.75 [Balco et al., 2008]. Recent models and data suggest that the ${ }^{26} \mathrm{Al} /{ }^{10} \mathrm{Be}$ production ratio may be greater than the consensus

320 value and may also be spatially variable as a function of latitude and elevation (see review in Corbett et al. [2017]). In fact, using the latest CRONUS-Earth production rate calibration data [Borchers et al., 2016] and the LSD scaling scheme [Lifton et al., 2014] we calculate ${ }^{26} \mathrm{Al} /{ }^{10} \mathrm{Be}$ spallation production rate ratios for the East Australian continental margin between 6.97 and 7.24 (see below). However, any conclusions arrived at by using the ratio of 6.75 will also hold for larger ${ }^{26} \mathrm{Al} /{ }^{10} \mathrm{Be}$ production ratio values and so using the consensus value is appropriate. Calculated ${ }^{10} \mathrm{Be}$ and ${ }^{26} \mathrm{Al}$ denudation rates and sediment storage durations are reported in Tables S4 and S5.

\subsection{Geospatial analyses}

We use a $30 \mathrm{~m}$ resolution SRTM DEM to calculate a range of topographic metrics including 330 slope, local relief, and normalised channel steepness $\left(k_{\mathrm{sn}}\right)$. We also extract long profiles for all streams, and in all analyses that involved the extraction of the stream network we use a minimum threshold accumulation area of $1 \mathrm{~km}^{2}$ [Jenson \& Domingue, 1988; Tarboton et al., 1991]. We calculate slope in ArcGIS, following the algorithm of Horn [1981], and we calculate local relief with the Focal Statistics tool in ArcGIS using circular neighbourhoods of 1,2 , and $5 \mathrm{~km}$ radii. We calculate normalised channel steepness with the TAK package for MATLAB [Forte \& Whipple, 2019] using the KsnChiBatch tool with the output parameter set to ' $k s n$ '. The latter produces a stream network with $k_{s n}$ values for each stream segment, as opposed to a continuous raster with interpolated $k_{\text {sn }}$ values. We use these raw stream network $k_{\text {sn }}$ values as opposed to an interpolated $k_{\text {sn }}$ raster to calculate our summary 340 statistics for each basin. Thus, for basins where we compile data from the literature and where $k_{\text {sn }}$ values have been reported [e.g., Mandal et al., 2015; Godard et al., 2019], our 
recalculated $k_{\mathrm{sn}}$ values may be higher due to the fact that interpolated $k_{\mathrm{sn}}$ rasters extend to hillslope grid cells where interpolated values will be lower. However, our use of $k_{\mathrm{sn}}$ and other topographic metrics is purely for exploring first order relationships between these and ${ }^{10} \mathrm{Be}$-derived denudation rates, and so values calculated here are appropriate for this purpose. In instances where we compare our Australian data with denudation rates from other passive continental margins, for consistency with the OCTOPUS database, and to avoid recalculating data that is already in this database, we also calculate slope and $k_{\mathrm{sn}}$ for all Australian basins using a $90 \mathrm{~m}$ resolution SRTM DEM.

350

We use modern mean annual rainfall as a proxy for climate across the study area. We extracted annual rainfall values for each river basin using the WorldClim v.2.1 database [Fick \& Hijmans, 2017]. The rainfall data is based on weather station records for the period 1970 -2000 and was obtained by interpolation at a resolution of $\approx 1 \mathrm{~km}$ using thin-plate splines with covariates including elevation and distance to the coast [Fick \& Hijmans, 2017]. Modern rainfall values for east Australia are similar in magnitude and also in spatial distribution to rainfall values predicted for this area for the Mid-Holocene ( $\approx 6 \mathrm{ka})$ and the Last Glacial Maximum ( $\approx 22 \mathrm{ka}$ ) as part of simulations using global climate models within the Coupled Model Intercomparison Project Phase 5 (CMIP5) [Meehl et al., 2000; Taylor et al., 2012] (Figure S2). Annual rainfall values are also similar to those predicted for the last interglacial [Otto-Bliesner et al., 2006] (Figure S2). Thus, although the WorldClim rainfall data only covers a period of 30 years, in contrast to the integration timescale for ${ }^{10} \mathrm{Be}$ derived denudation rates $\left(10^{4}-10^{5}\right.$ years; Table S4), using these data to explore first-order relationships between millennial-scale denudation rates and rainfall is appropriate.

To explore hydrological variability as a potential control on ${ }^{10} \mathrm{Be}$ and ${ }^{26} \mathrm{Al}$ inventories in sediment, we aggregated Rustomji et al.'s [2009] flood variability metrics for each eastdraining mainstem basin. Rustomji et al. [2009] considered three flood variability metrics, namely: (1) the $Q_{50}: Q_{2}$ flood quantile ratio calculated from a fitted probability density function, (2) a power law scaling coefficient, and (3) the Flash Flood Magnitude Index (FFMI). These metrics are based on flow data from 424 unregulated gauging stations with a median record length of 38 years. Of the three metrics, Rustomji et al. [2009] recommend (1) and (2), however, for completeness we include all three in our analyses. We also 
summarise statistics pertaining to the depth of regolith - as a proxy for the volume of unconsolidated sediment available in each basin - using the publicly available depth-ofregolith raster dataset for the Australian continent [Wilford et al., 2015]. The depth-ofregolith raster is based on a database of over 350,000 drillhole records with information on the depth of the boundary between regolith and bedrock at each bore location [Wilford et al., 2016]. We use the flood variability metrics and the depth-of-regolith data to explore potential causes for the observed spatial pattern in ${ }^{26} \mathrm{Al} /{ }^{10} \mathrm{Be}$ ratios. Lastly, we explore first order linkages between ${ }^{10} \mathrm{Be}$-derived denudation rates and lithology by calculating the predominant rock-type in each basin using the Geoscience Australia 1:2.5 million scale Surface Geology of Australia digital dataset [Raymond et al., 2012].

Given the distinctive variability in hypsometry that characterises basins draining an archtype passive margin (i.e., low relief upland plateau, a steep escapement zone, and a low relief, low elevation coastal plain), it is important to explore in more detail the quantitative relationships between topography, rainfall, and denudation rates. We calculate summary statistics (such as mean, median, standard deviation) for all grid cells of a given metric (e.g., slope, relief, $k_{\mathrm{sn}}$, rainfall) in each basin, as well as summary statistics only for those grid cells (of a metric) that have values greater than the $90^{\text {th }}$ percentile. Given that the escarpment zone will have the steepest slopes, highest local relief and $k_{s n}$, and due to orographic effects, also the highest rainfall values, inspecting these metrics at values above the $90^{\text {th }}$ percentile effectively allows us to isolate and focus our analysis on the escarpment zone. Results are summarised in Tables S6 to S11.

\section{Results}

\section{1. ${ }^{10}$ Be-derived denudation rates}

Denudation rates ${ }^{*}$ in mainstem samples from east-draining basins range between $7.7 \pm 1.9$ $( \pm 1 \sigma) \mathrm{mm} \mathrm{kyr}^{-1}$ (Mary) and $54.6 \pm 13.7 \mathrm{~mm} \mathrm{kyr}^{-1}$ (North Johnstone). Denudation rates in

\footnotetext{
* In situ-produced cosmogenic nuclides accumulate as material moves towards the surface by the removal of material above and so they record the total (i.e., physical and chemical) rate of mass removal from the Earth's surface. ${ }^{10} \mathrm{Be}$-derived denudation rates represent averages over timescales that depend on the denudation rates themselves (see von Blanckenburg [2005] for details). For the East Australian continental margin denudation rates presented here, averaging timescales are in the order of $10^{4}-10^{5}$ years (see Table S4).
} 
tributary samples range between $3.0 \pm 0.7 \mathrm{~mm} \mathrm{kyr}^{-1}$ (Burdekin) and $70.2 \pm 18.9 \mathrm{~mm} \mathrm{kyr}^{-1}$ (Liverpool). For west-draining basins, denudation rates range between $4.8 \pm 1.2 \mathrm{~mm} \mathrm{kyr}^{-1}$ (Barcoo) and $15.4 \pm 3.6 \mathrm{~mm} \mathrm{kyr}^{-1}$ (Maranoa) in mainstem samples, and between $4.4 \pm 1.0$ $\mathrm{mm} \mathrm{kyr} \mathrm{r}^{-1}$ (Murrumbidgee) and $38.5 \pm 7.8 \mathrm{~mm} \mathrm{kyr}^{-1}$ (Murray) in tributary samples. Overall, ${ }^{10} \mathrm{Be}$-derived denudation rates are higher in basins on the eastern side of the continental divide as compared to those on the western side (Figures 4 and 5) and their interquartile ranges (IQR) do not overlap (Figure 5). In the majority of basins where both mainstem and tributary samples are available, tributary samples yield ${ }^{10} \mathrm{Be}$-derived denudation rates that are overall higher or the same (within uncertainty) as the denudation rates obtained for the mainstem sample (Figure 6). Notwithstanding, in several basins, namely, Murrumbidgee, Fitzroy, Burdekin, and North Johnstone, tributary samples yield ${ }^{10}$ Be-derived denudation rates that are overall lower or the same (within uncertainty) as the denudation rates obtained for the mainstem sample (Figure 6). In terms of south - north trends, mainstem 410 denudation rates east of the divide average to $11.6 \mathrm{~mm} \mathrm{kyr}^{-1}$ for the basins draining the southern coast of Victoria (Mitchell to Genoa; Figure 4A). Denudation rates then increase to an average of $27.3 \mathrm{~mm} \mathrm{kyr}^{-1}$ for the south-eastern sector of the margin (Bega to Logan; Figure $4 \mathrm{~A})$, with rates being similar in most basins $\left(\approx 20 \mathrm{~mm} \mathrm{kyr}^{-1}\right)$ except three with denudation rates of $\approx 40-45 \mathrm{~mm} \mathrm{kyr}^{-1}$ (Figure $4 \mathrm{~A}$ ). Northern sector rates (Bremer to Daintree) average to $20.5 \mathrm{~mm} \mathrm{kyr}^{-1}$, though the range is rather large (between $\approx 8$ and $\approx 55$

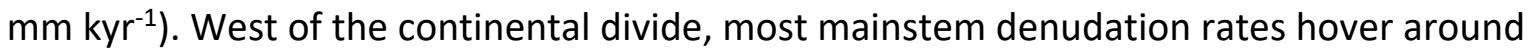
$10 \mathrm{~mm} \mathrm{kyr}^{-1}$ with a minor south to north decrease. Tributary denudation rates show similarly low values apart from the upper Murray averaging to $31.0 \mathrm{~mm} \mathrm{kyr}^{-1}$. 

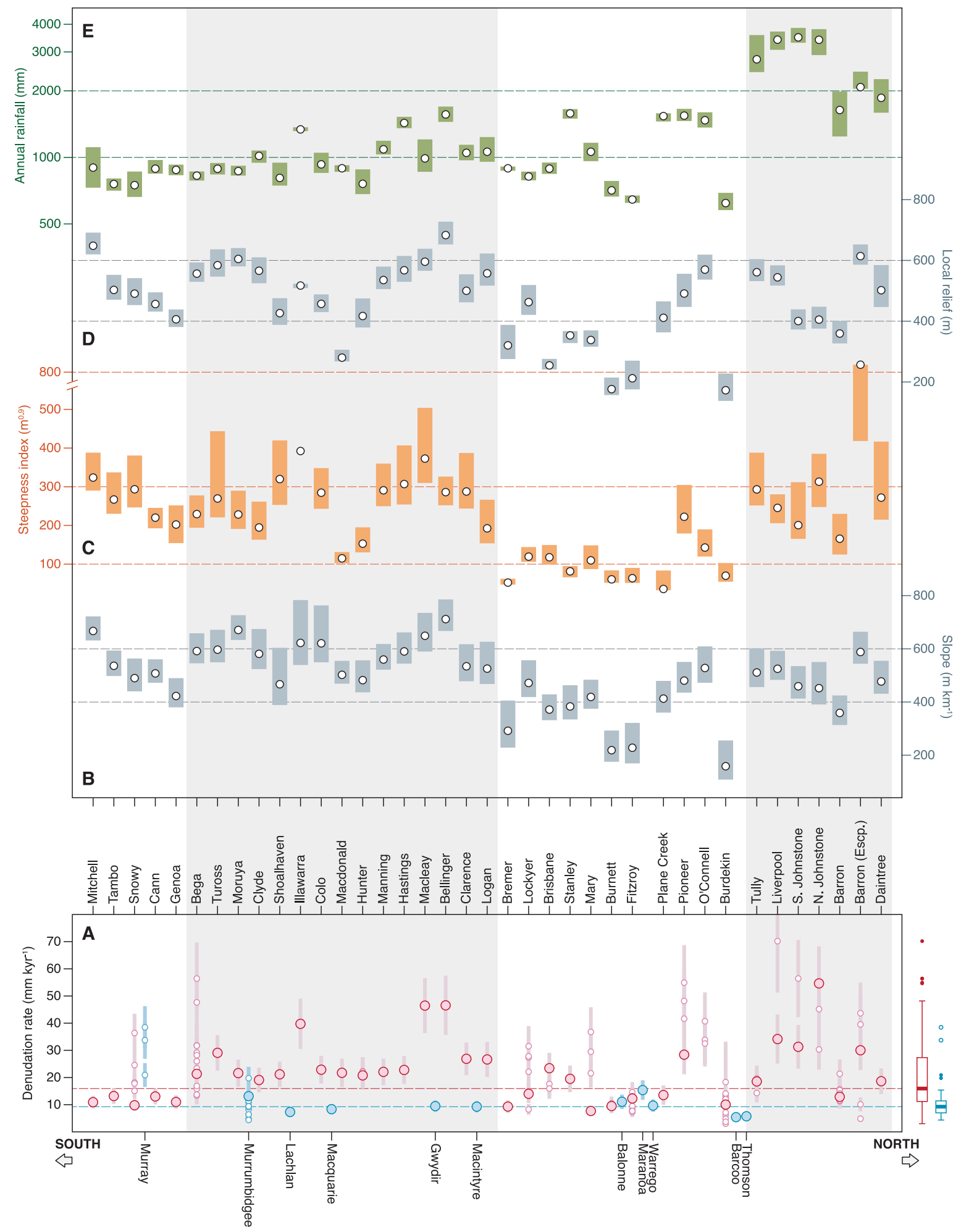
Figure 4: ${ }^{10}$ Be-derived denudation rates, topographic metrics and annual rainfall. (A) Distribution of denudation rates for mainstem (large circles) and tributary (small circles) samples from the eastern (red) and western (blue) sides of the continental divide, ordered from south to north. Basins east of the continental divide record overall higher denudation rates than basins west of the divide (red and blue dashed lines and box plots). (B-D) Slope, normalised channel steepness $\left(k_{s n}\right)$, and local relief values for each mainstem basin east of the continental divide, calculated using only values from those grid cells where each metric is greater than the $90^{\text {th }}$ percentile. Topographic metrics were extracted from a $30 \mathrm{~m}$ resolution SRTM DEM. (E) Mean annual rainfall values for each mainstem basin east of the continental divide, calculated using all values in each basin. Black circles show median values and coloured boxes represent interquartile ranges. Grey bands indicate the southeastern and northernmost sections of the margin where ${ }^{10}$ Be-derived denudation rates are consistently higher than elsewhere. Horizontal dashed lines are to guide the eye. Note the logarithmic scale used in (E).
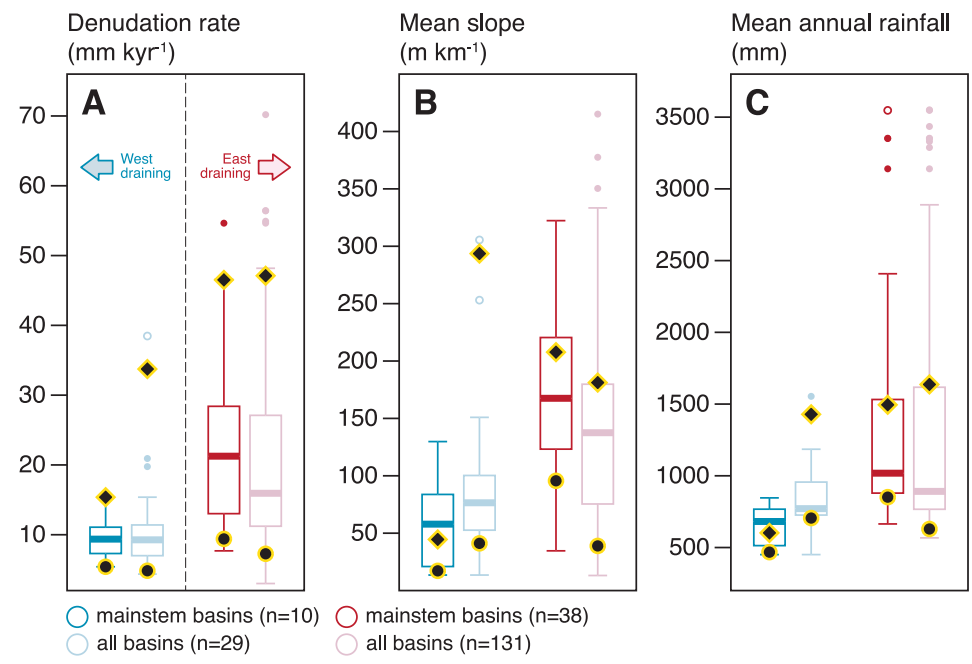

Figure 5: ${ }^{10}$ Be-derived denudation rates, mean slope, and mean annual rainfall, east and west of the continental divide. (A-C) Black diamonds and black circles represent the median of denudation rate, mean slope, and mean annual rainfall for basins with the 10\% highest (diamonds) and 10\% lowest (circles) denudation rates, respectively. Slope was extracted from a $90 \mathrm{~m}$ resolution SRTM DEM. See text for more details. 

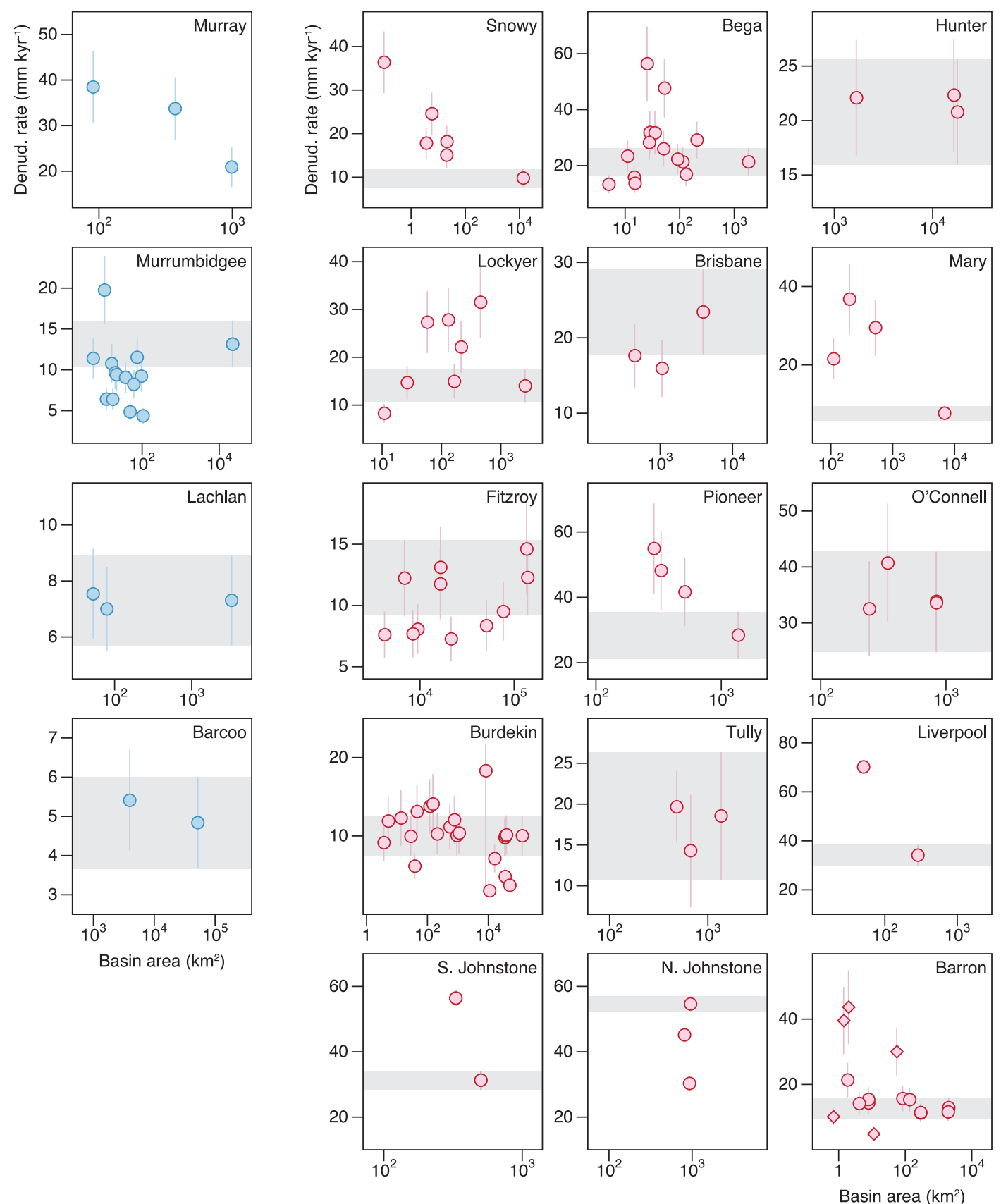

Figure 6: ${ }^{10} \mathrm{Be}$ denudation rate vs. area for basins where tributary samples are available. Blue and red circles show samples from basins located west (blue) and east (red) of the continental divide. Grey band shows ${ }^{10}$ Be denudation rate range at 1-sigma uncertainty level for the mainstem sample. No mainstem sample is available for the Murray River. For the Barron, diamonds represent basins draining the escarpment zone. 


\subsection{Links between denudation rates, topographic metrics, and rainfall}

The east - west differences in denudation rates recorded in the mainstem basins are also mirrored by differences in their topography and annual rainfall, namely both average slope and average annual rainfall are higher in east-draining basins as compared to those on the western side of the continental divide (Figure 5). East of the divide, topographic metrics (such as slope, $k_{\mathrm{sn}}$, and local relief), are generally lower in the northern sector of the margin (i.e., north of Logan), although there is considerable variability in values throughout (Figure 4B-D). Annual precipitation increases from south to north and decreases from east to west with the Great Escarpment exerting a strong orographic control: larger basins in the northern sector of the margin (e.g., Burnett, Fitzroy, Burdekin) receive less rainfall than basins in the southern sector (e.g., Macquarie Rivulet in the Illawarra and Bellinger), mainly because in the south, the continental divide is closer to the coast making the Great Escarpment a more pronounced and an important orographic barrier (Figure 4E). The strong orographic control is also evident in the northernmost basins (e.g., Tully, Johnstone, Liverpool), where the Great Escarpment is also closer to the coast.

To assess potential controls on denudation rates, in Figure 7 we examine the relationship between ${ }^{10} \mathrm{Be}$-derived denudation rates and the topographic metrics and annual precipitation for each basin. East of the divide, there is a weak correlation between denudation rate and topographic metrics (slope, $k_{\mathrm{sn}}$, and local relief) for mainstem basins

$440 \quad\left(R^{2}=0.13-0.16\right)$. The correlation between denudation rate and slope, and denudation rate and $k_{\mathrm{sn}}$ is stronger $\left(\mathrm{R}^{2}=0.27\right.$ and 0.24 , respectively) when topographic metrics are calculated using only values greater than the $90^{\text {th }}$ percentile, suggesting that the escarpment zone is an important contributor of sediment (and therefore ${ }^{10} \mathrm{Be}$ signal) to the outlet of these basins. $R^{2}$ values are, however, strongly influenced by several outliers (symbols with no fill in Figure 7). When these outliers are excluded (red regression lines in Figure 7 ), $R^{2}$ values increase to $0.25,0.35$, and 0.44 (slope, $k_{\text {sn }}$, and local relief) when all metric values are used, and to $0.44,0.41$, and 0.30 when only values greater than the $90^{\text {th }}$ percentile are used (Figure 7A). The correlation between denudation rate and topographic metrics becomes stronger when looking at the smaller tributary basins. To maximise the number and geographic spread of tributary basins that we include in our analysis and at the 
same time to minimise topographic heterogeneity within each basin, in Figure 7B we limit our analysis to basins with areas $<150 \mathrm{~km}^{2}$. For these basins, the strongest correlation $\left(\mathrm{R}^{2}=\right.$ 0.43 ; Figure 7B2) is found between denudation rate and $k_{\mathrm{sn}}$. Basin slope and local relief yield $R^{2}$ values of 0.31 and 0.34 , respectively. Here too, $R^{2}$ values are strongly influenced by several outliers. When these outliers are excluded, $R^{2}$ values increase to $0.64,0.71$, and 0.70 for slope, $k_{\text {sn }}$, and local relief, respectively.
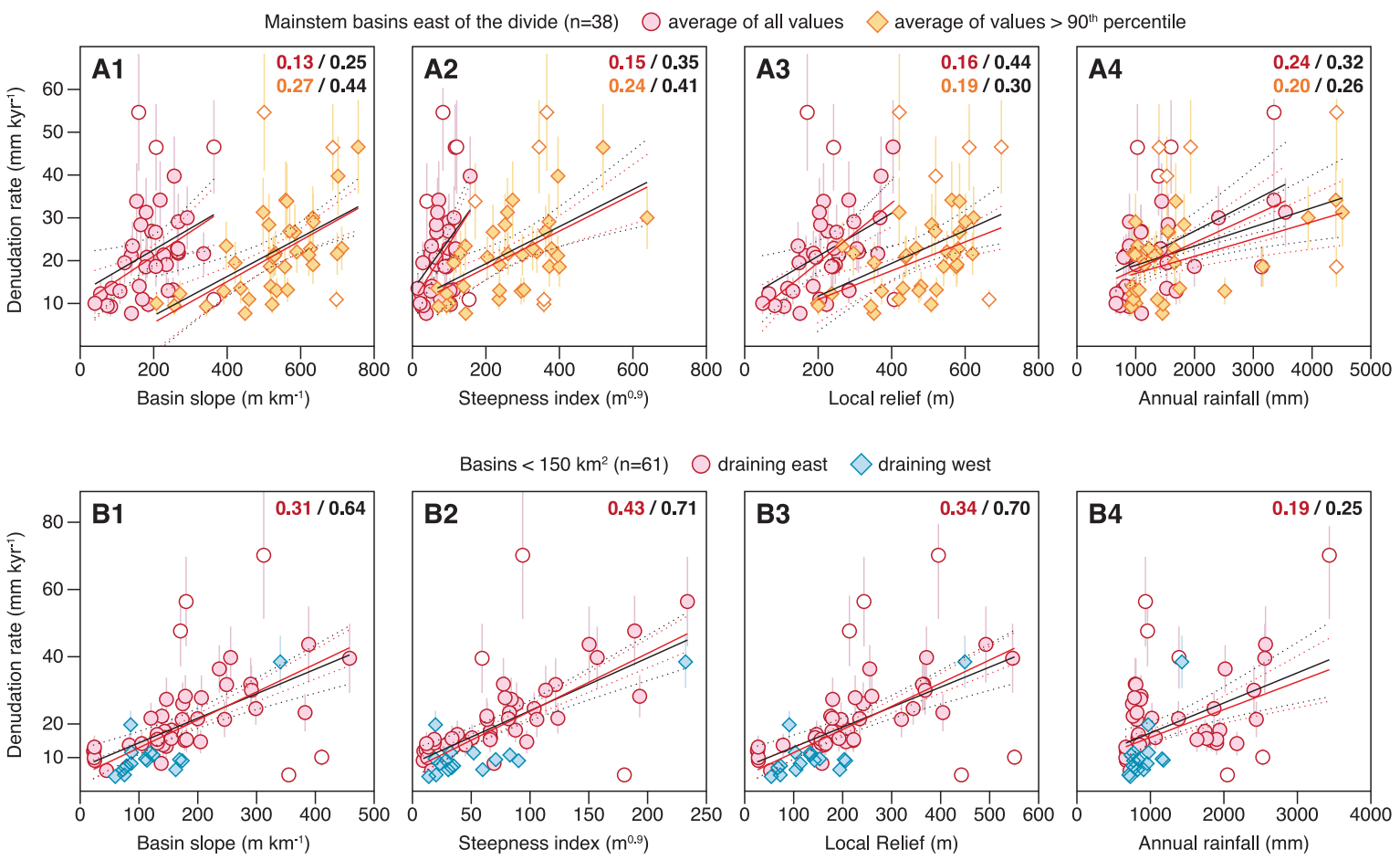

Figure 7: ${ }^{10}$ Be-derived denudation rate vs. topographic metrics and annual rainfall. (A) Plots for east-draining mainstem basins only. Red circles are mean topographic metrics and mean annual rainfall calculated using all grid cells, whereas orange diamonds were calculated using only values greater than the $90^{\text {th }}$ percentile. (B) Plots for both east-and west-draining basins with areas smaller than $150 \mathrm{~km}^{2}$. Topographic metrics were extracted from a $30 \mathrm{~m}$ resolution SRTM DEM. Symbols with no fill denote outliers defined as points with residuals $>1.5 \sigma$. Dotted lines show 95\% confidence intervals. Regression lines and confidence envelopes were calculated using all datapoints (black) and excluding outliers (red). Numbers in red, orange, and black are values of the coefficient of determination $-R^{2}$ (red and orange: all data points; black: outliers excluded).

The correlation between denudation rate and annual rainfall (outliers excluded) is weak: $R^{2}$ $=0.32 / 0.26$ for mainstem basins and $\mathrm{R}^{2}=0.25$ for basins $<150 \mathrm{~km}^{2}$. Notwithstanding these low $\mathrm{R}^{2}$ values, Figure 5 suggests that annual rainfall does exert control on denudation rates 
as both the highest and lowest ${ }^{10} \mathrm{Be}$-derived denudation rates, at least east of the divide, occur in basins that not only record the highest (and lowest) mean slopes but also record the highest (and lowest) annual rainfall values (Figure 5, black diamonds and circles).

\section{3. ${ }^{26} \mathrm{Al} /{ }^{10} \mathrm{Be}$ ratios and sediment storage durations}

We measured both ${ }^{26} \mathrm{Al}$ and ${ }^{10} \mathrm{Be}$ in 67 samples, 52 from east draining and 15 from west draining basins, equally split between mainstem and tributary samples. ${ }^{26} \mathrm{Al} /{ }^{10} \mathrm{Be}$ ratios range between $4.99 \pm 0.31$ ( $\pm 1 \sigma$ ) (Mitchell) and $7.86 \pm 0.77$ (Don), east of the continental divide, and between $3.96 \pm 0.32$ (Barcoo) and $6.39 \pm 0.40$ (Maranoa), west of the continental divide (Table S5). On both sides of the divide, all but a few of the samples plot below the ${ }^{26} \mathrm{Al} /{ }^{10} \mathrm{Be}$ steady-state erosion - continuous exposure envelope (Figure $8 \mathrm{A \& B}$ ), indicating that those samples have experienced complex exposure histories. East of the continental divide, samples that record ${ }^{26} \mathrm{Al} /{ }^{10} \mathrm{Be}$ ratios statistically lower than the consensus ${ }^{26} \mathrm{Al} /{ }^{10} \mathrm{Be}$ spallation production rate ratio of 6.75 , at the $95 \%$ confidence level, (Figure 9A) cluster on the south coast of Victoria and in south-east Queensland and are predominantly from basins that also experience increased flood variability (Table S10, Figure 9C). We return to this observation later in the discussion below.

As noted above, we calculate the duration of sediment storage in basins with both ${ }^{26} \mathrm{Al}$ and ${ }^{10} \mathrm{Be}$ data assuming a two-step history: continuous exposure in the source zone followed by deep burial (during which production totally ceases) within the colluvial/fluvial system resulting in a decrease of the ${ }^{26} \mathrm{Al} /{ }^{10} \mathrm{Be}$ ratio from its initial input value, and finally recent reexposure. This approach is similar to that used in other studies [e.g., Wittmann et al., 2011; Hippe et al., 2012; Struck et al., 2018b; Fülöp et al., 2020] and involves several simplifying assumptions that cannot be validated and are likely not met due to spatially variable denudation rates and sediment mixing [cf., Bierman \& Steig, 1996]. Calculated sediment storage durations range between 0 and $\approx 730$ ka east of the continental divide and between $\approx 260$ and $\approx 1,100$ ka west of the continental divide (Table S5). Calculated values have large uncertainties and only 19 of the 67 calculated values are distinguishable from zero at the 95\% confidence level. 

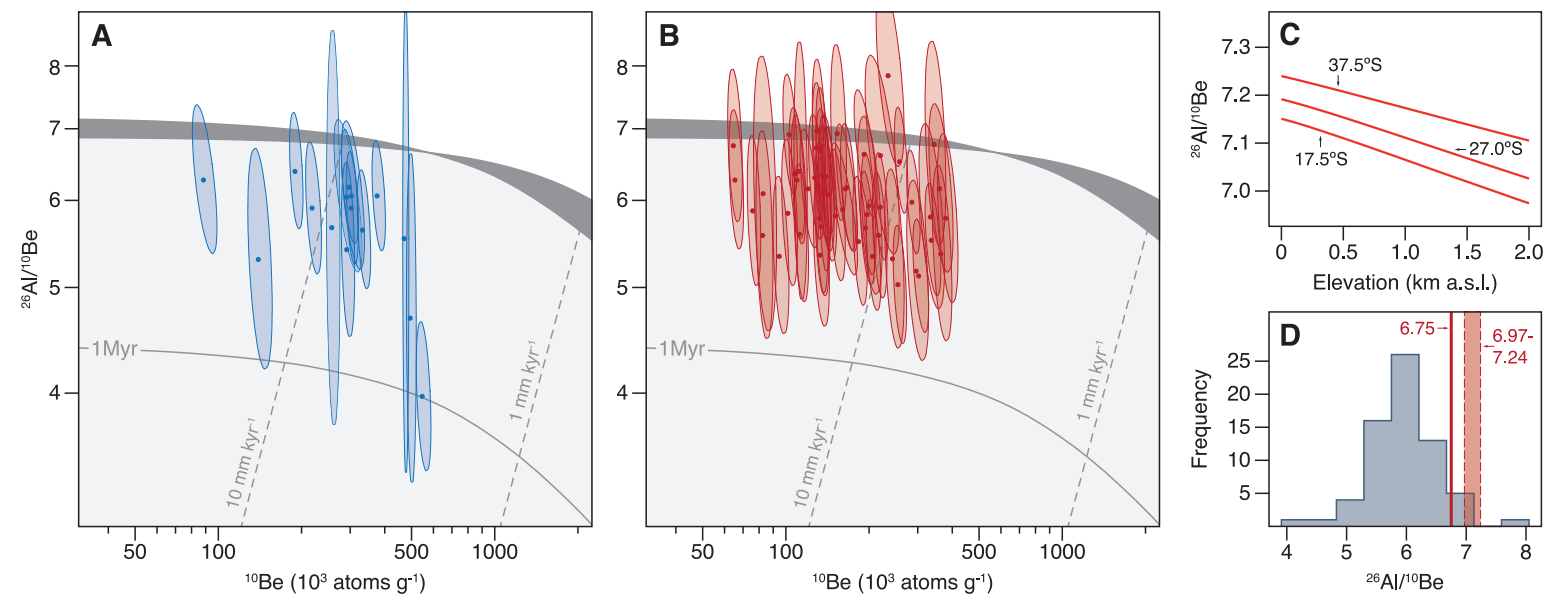

Figure 8: ${ }^{26} \mathrm{Al} /{ }^{10} \mathrm{Be}$ ratios. $(\mathrm{A})$ and $(\mathrm{B}){ }^{26} \mathrm{Al} /{ }^{10} \mathrm{Be}$ vs. ${ }^{10} \mathrm{Be}$ concentration plots for samples west $(A)$ and east $(B)$ of the continental divide, respectively. Samples that have experienced continuous exposure to cosmic radiation will plot within the dark-grey simple exposure/erosion history envelope. Samples that have experienced a complex exposure history involving one or more episodes of burial and cessation of nuclide production (i.e., samples undergoing storage) will plot in the light-grey shaded area. The distance between the simple exposure / erosion history envelope and a data point is proportional to the duration of burial, with samples buried for longer plotting further away from the darkgrey envelope. Grey curve shows 1 Myr burial isochron. Uncertainties (ellipses) are shown at 2-sigma level. (C) ${ }^{26} \mathrm{Al} /{ }^{10} \mathrm{Be}$ spallation production rate ratios (red lines) calculated for elevation and latitude values representative for the East Australian continental margin using the CRONUS-Earth production rate calibration data [Borchers et al., 2016] and the LSD scaling scheme [Lifton et al., 2014]. (D) Frequency distribution of measured ${ }^{26} \mathrm{Al} /{ }^{10} \mathrm{Be}$ ratios $(n=67)$. Red vertical line indicates the consensus ${ }^{26} \mathrm{Al} /{ }^{10} \mathrm{Be}$ spallation production rate ratio of 6.75 [Balco et al., 2008] and the red vertical band indicates the range of spallation production rate ratios calculated in (C). Note how almost the entire population of ${ }^{26} \mathrm{Al} /{ }^{10} \mathrm{Be}$ ratios plots to the left of the consensus ${ }^{26} \mathrm{Al} /{ }^{10} \mathrm{Be}$ spallation production rate ratio of 6.75 . 

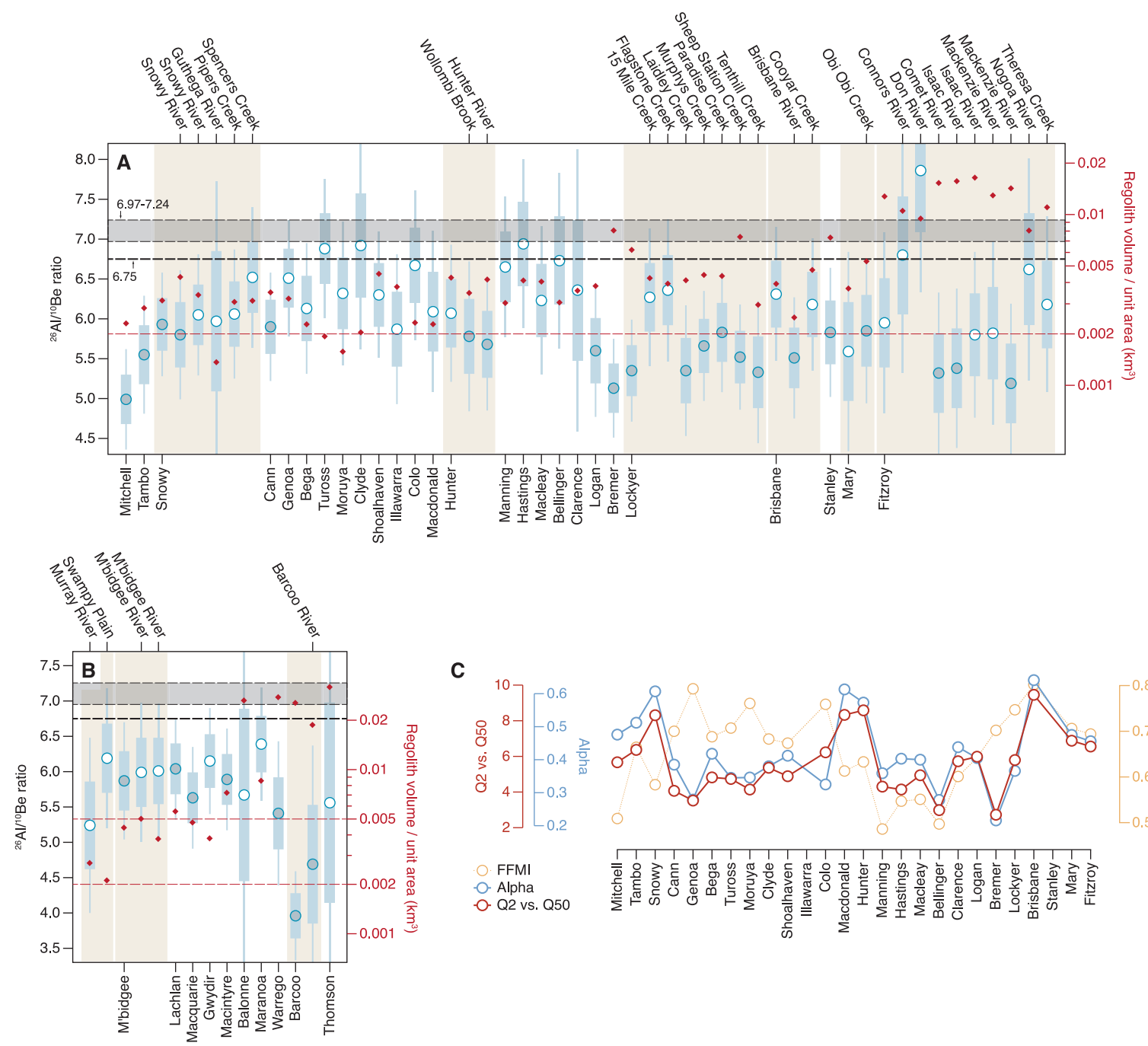

C
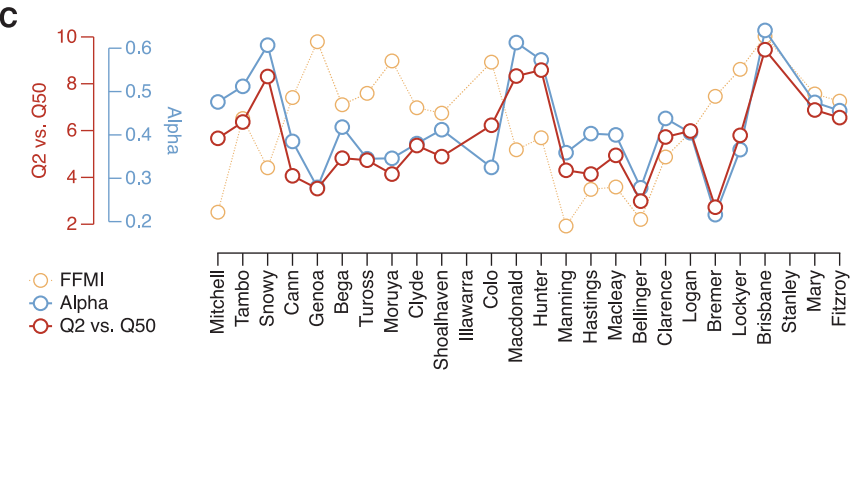

Figure 9: ${ }^{26} \mathrm{Al} /{ }^{10} \mathrm{Be}$ ratios and flood variability. $(A)$ and $(B){ }^{26} \mathrm{Al} /{ }^{10} \mathrm{Be}$ ratios (circles) for samples east $(A)$ and west $(B)$ of the continental divide, respectively. Whiskers indicate uncertainties at the 95\% confidence level and darker blue boxes indicate uncertainties at the $68 \%$ confidence level. Blue circles are ${ }^{26} \mathrm{Al} /{ }^{10} \mathrm{Be}$ ratios that are distinguishable from the consensus ${ }^{26} \mathrm{Al} /{ }^{10} \mathrm{Be}$ spallation production rate ratio of 6.75 (black dashed horizontal line) at the $95 \%$ confidence level. Black horizontal band indicates the range of spallation production rate ratios calculated in Figure $8 C$. Red diamonds represent regolith volume per unit basin area, calculated using Wilford et al.'s [2015] depth-of-regolith data. Ivory vertical bands group samples belonging to the same mainstem basin such that basin names on bottom $x$-axis are mainstem samples only. Red dashed lines are to guide the eye. (C) Flood variability metrics for basins east of the continental divide calculated using data from Rustomji et al. [2009]. FFMI: mean flash flood magnitude index calculated using the monthly peaks-over-threshold flood series; Alpha: mean power law scaling coefficient; Q2 vs. Q50: mean flood quantile ratio. Alpha and Q2 vs. Q50 are the recommended metrics by Rustomji et al. [2009], and FFMI is shown only for completeness. 


\section{Discussion}

\section{$5.1{ }^{10} \mathrm{Be}$-derived denudation rates and their global significance}

Short-term erosion rates, inferred from measurements of sediment yields have been shown to vary globally by up to six orders of magnitude between 0.001 and $1,000 \mathrm{~mm} \mathrm{yr}^{-1}$, the highest rates resulting from the transient response of the landscape to disturbance by volcanic eruptions, rapid climate change, and modern agriculture and land use change [Koppes \& Montgomery, 2009; Korup, 2012]. Likewise, millennial-scale denudation rates calculated using cosmogenic ${ }^{10} \mathrm{Be}$ have been shown to also vary globally by up to five orders of magnitude between $0.1 \mathrm{~mm} \mathrm{kyr}^{-1}$ and 10,000 mm kyr ${ }^{-1}$ (or 0.0001 to $10 \mathrm{~mm} \mathrm{yr}^{-1}$ ) [Codilean et al., 2018]. Knowing these extremes is useful in understanding how landscapes might respond to tectonic and climatic forcings, the timescales necessary to reach a new equilibrium state, and to evaluate the conditions under which steady state is attainable. From a long-term landscape evolution perspective, however, more important than knowing the extremes, is understanding what constitute representative (or 'normal') rates of landscape denudation for a given setting.

Within the Australian context, it was realised very early on [e.g., Young, 1983; Bishop, 1985] that rates of landscape lowering along the eastern margin have been very slow and relatively constant throughout the Tertiary in comparison to rates reported for the more humid Northern Hemisphere settings that were regarded as the 'normal' at the time [e.g., Thornbury, 1969]. The low rates of lowering have since been confirmed by more recent studies, Bishop [2007] summarising representative rates for tectonically quiescent landscapes to be in the order of 5 to $10 \mathrm{~mm} \mathrm{kyr}^{-1}$. More importantly, however, these early studies - in particular Young [1983] - have also suggested that the perception that Northern Hemisphere rates of erosion were the 'normal' and that those recorded in Australia were, for example, anomalously low was probably incorrect. In fact, the opposite may be true: denudation rates recorded in non-glaciated, tectonically quiescent settings are the 'normal' and those recorded in tectonically active settings or from areas affected by Quaternary glaciations are anomalously high in comparison. Our understanding of rates of landscape lowering has improved substantially since the early works of Young [1983] and Bishop [1985]. In particular, in the last decade, the availability of global datasets of both short-term 
and millennial-scale erosion rates have permitted unprecedented synoptic studies of denudation aiming to infer global-scale trends from these data [e.g., Koppes \& Montgomery, 2009; Milliman \& Farnsworth, 2011; Portenga \& Bierman, 2011; Willenbring et al., 2013; Harel et al., 2016]. The comprehensive dataset of ${ }^{10} \mathrm{Be}$-derived denudation rates presented in this study, in conjunction with ${ }^{10} \mathrm{Be}$ data from the OCTOPUS database [Codilean et al., 2018] allows us to re-visit the question of what constitute representative rates of landscape denudation, and to place East Australian denudation rates into a global context.

To achieve a meaningful comparison between the East Australian basins and those found in the OCTOPUS database (Figure $10 \mathrm{~A} \& \mathrm{~B}$ ), we first need to separate the basins that are located in tectonically passive settings from those in tectonically active settings. To do the latter we use Kreemer et al.'s [2014] Global Strain Rate Model (v.2.1) and consider all basins that fall completely within areas classed by the model as rigid plates as being in a tectonically passive setting. Conversely, all basins with non-zero mean values for the model strain rate field - even if partially overlapping areas classed as rigid plates - are considered to belong to the tectonically active group. Given that there is no definitive definition or universally accepted set of metrics to distinguish between tectonically active and passive settings, the above approach, although simplistic, is based on a quantitative framework that allows us to carry out a first-order statistical inter-comparison of the datasets. 

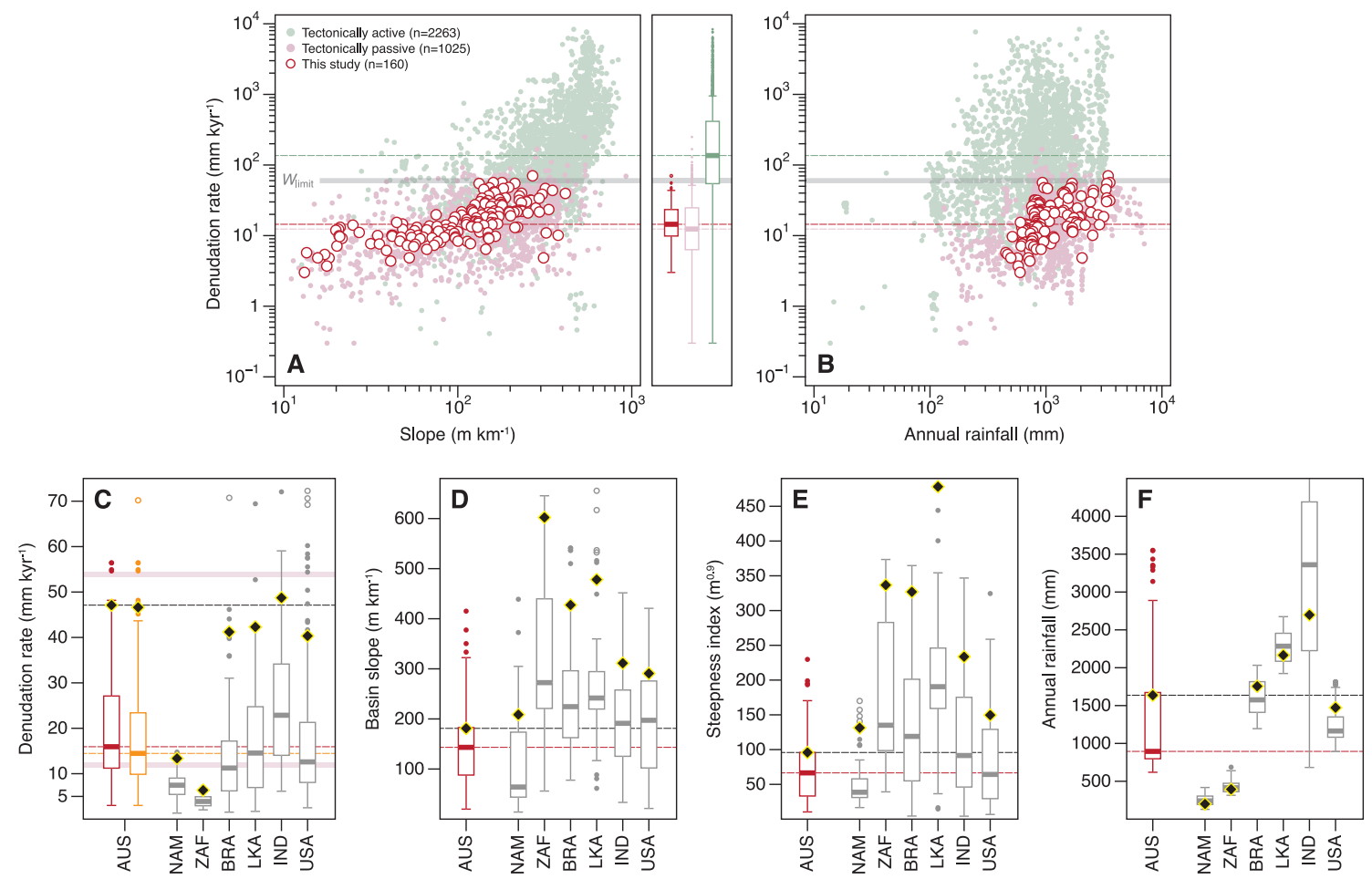

Figure 10: East Australian denudation rates in a global context. $(A)$ and $(B){ }^{10} B e$-derived denudation rate vs. mean basin slope $(A)$ and mean annual rainfall $(B)$, comparing data from the East Australian margin with the global denudation rates from the OCTOPUS database. Dashed horizontal lines are median values: light magenta-basins from tectonically passive settings, light green - basins from tectonically active settings, red this study. Horizontal grey band ( $W_{\text {limit }}$ ) represents the silicate weathering speed limit (i.e.,

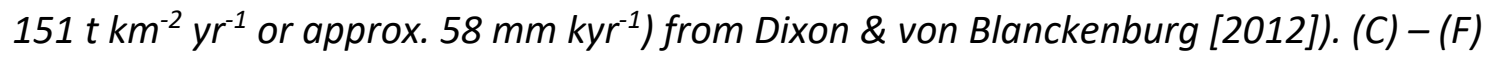
Box plots showing ${ }^{10}$ Be-derived denudation rates $(C)$, mean basin slope $(D)$, mean normalised channel steepness $\left(k_{s n}\right)(E)$, and mean annual rainfall $(F)$ for basins from this study (AUS) and other passive continental margin settings: Namibia (NAM), South Africa (ZAF), Eastern Brazil (BRA), Sri Lanka (LKA), Western Ghats (IND), and the Appalachian Mountains (USA). Red box plots show data for Australian basins to the east of the continental divide and orange box plot includes data from both sides of the divide. Black diamonds represent the median of denudation rate, mean slope, mean $k_{s n}$, and mean annual precipitation, respectively, for basins with the $10 \%$ highest denudation rates. Red (and orange) horizontal dashed lines represent median values for all Australian datapoints, and black horizontal dashed lines represent median values calculated only for Australian basins with the $10 \%$ highest denudation rates. Light magenta horizontal bands in (C) represent median denudation rate values for all tectonically passive basins (lower band) and for those with the 10\% highest denudation rates (upper band). Topographic metrics were extracted from a $90 \mathrm{~m}$ resolution SRTM DEM. See text for more details. 
Using the above approach to split the global denudation rate data, we calculate a median global ${ }^{10} \mathrm{Be}$-derived denudation rate for tectonically passive regions of $12.4 \mathrm{~mm} \mathrm{kyr}^{-1}(n=$ $1025)$ and similarly a value of $136 \mathrm{~mm} \mathrm{kyr}^{-1}(n=2263)$ for tectonically active regions. The majority (95\%) of the data sit between 2 and $65 \mathrm{~mm} \mathrm{kyr}^{-1}$, a small range when compared with the five orders of magnitude rage of the entire global dataset. The distribution of the East Australian data is virtually identical to the global tectonically passive data, with the median denudation rate being $14.5 \mathrm{~mm} \mathrm{kyr}^{-1}(n=160)$, and $95 \%$ of the data siting between 5 and $55 \mathrm{~mm} \mathrm{kyr}^{-1}$. In addition, the East Australian denudation rates are also similar to those found in other passive continental margin settings (Figure 10C). The only exceptions to the above are the Namibian (NAM) and South African (ZAF) margins, where the very low denudation rates have been attributed to hyper-arid conditions [Cockburn et al., 2000; Bierman \& Caffee, 2001; van der Wateren \& Dunai, 2001; Codilean et al., 2008; 2014] and to strong lithological control [Scharf et al., 2013], respectively. The similarities are also present when looking at the extremes. For example, the median of the highest $10 \%$ denudation rates in all but the Namibian and South African margins are very similar (Figure 10C, black diamonds and black dashed line) despite substantial differences between the margins in both the topography and the annual rainfall of the basins (Figure 10D-F, black diamonds and black dashed lines).

Young and McDougall [1993], citing evidence on the widespread preservation of basaltic lavas that flowed into river valleys across the uplands of south-eastern Australia, have highlighted the 'anomalous' persistence of transience in these landscapes for tens of millions of years. The data compiled in Figure 10, however, show very clearly that there is nothing anomalous about the East Australian margin as far as denudation rates are concerned. In fact, given that tectonically quiescent terrains occupy a large proportion of the Earth's continental surface ${ }^{\dagger}$, we can argue that the relatively low rates at which they are lowering (as compared to those in tectonically active settings), and the protracted timescales of landscape transience that these low rates imply, are the normal globally, rather than the exception. In contrast, tectonically active and / or glacially affected terrains

\footnotetext{
'Based on the Global Strain Rate Model (GSRM v.2.1) [Kreemer et al., 2014], only $\approx 25 \%$ of the Earth's continental topography (only $18 \%$ if Antarctica is included) records non-zero values for the model strain rate field.
} 
such as Taiwan, New Zealand, Alps, Himalaya record ${ }^{10}$ Be-derived denudation rate above the global $90^{\text {th }}$ percentile $\left(\approx 1,000 \mathrm{~mm} \mathrm{kyr}^{-1}\right)$ for tectonically active regions, and so should be perceived as the anomaly.

Denudation rates in tectonically passive settings are not only substantially lower than those from tectonically active settings (Figure 10A - box plots and dashed horizontal lines) but also there seems to be a limit to how high they can be. This observation is supported by the fact that the medians of the top $10 \%$ denudation rates recorded in the various passive margins (Figure 10C, black diamonds) are similar despite differences in topography and precipitation (Figure 10D-F, black diamonds). These median denudation rate values, and in fact the $95^{\text {th }}$ percentile denudation rate for all tectonically passive basins $\left(\approx 53 \mathrm{~mm} \mathrm{kyr}{ }^{-1}\right)$, are very similar to Dixon \& von Blanckenburg's [2012] 'silicate weathering speed limit' ( $\approx 58 \mathrm{~mm}$ $\mathrm{kyr}^{-1}$ ) calculated as the $95^{\text {th }}$ percentile of global soil weathering rates (Figure 10A\&B, grey band labelled $W_{\text {limit }}$. This last observation suggests that in post-orogenic terrain, the overall rates of topographic decay have a speed limit that is imposed by the rate at which rock is converted to soil by chemical weathering.

\section{$580 \quad$ 5.2. Links between denudation rates and lithology}

A strong lithological control on denudation rates has been documented in numerous postorogenic landscapes, more recent salient examples including the Cape Mountains of South Africa [Scharf et al., 2013], the Pyrenees [Bernard et al., 2019], the Kimberley plateau in Western Australia [Cazes et al., 2020], and the Quadrilátero Ferrífero in Brazil [Peifer et al., 2020]. In contrast to the above, and despite well documented instances of a strong (localised) lithological control on escarpment retreat in south-eastern Australia [e.g., Nott et al., 1996], lithology does not seem to exert a first order control on ${ }^{10} \mathrm{Be}$-derived denudation rates along the East Australian passive margin (Figure 11). Median denudation rates for each major quartz-bearing lithological group vary in a narrow range (between $10-20 \mathrm{~mm} \mathrm{kyr}^{-1}$ ) as compared to the factor of 10 range in the total dataset, and denudation rate IQRs overlap for all groups. It is unlikely that the lack of a relationship is due to the scale of the drainage basins that are included in this study, as the same statistics are obtained when only including basins $<150 \mathrm{~km}^{2}$ (Figure 11, white boxplots). Notwithstanding the above, our data does not preclude the possibility of a strong lithological control at the landform scale, 
neither is it suitable to exploring such local scale linkages between lithology and rates of denudation.

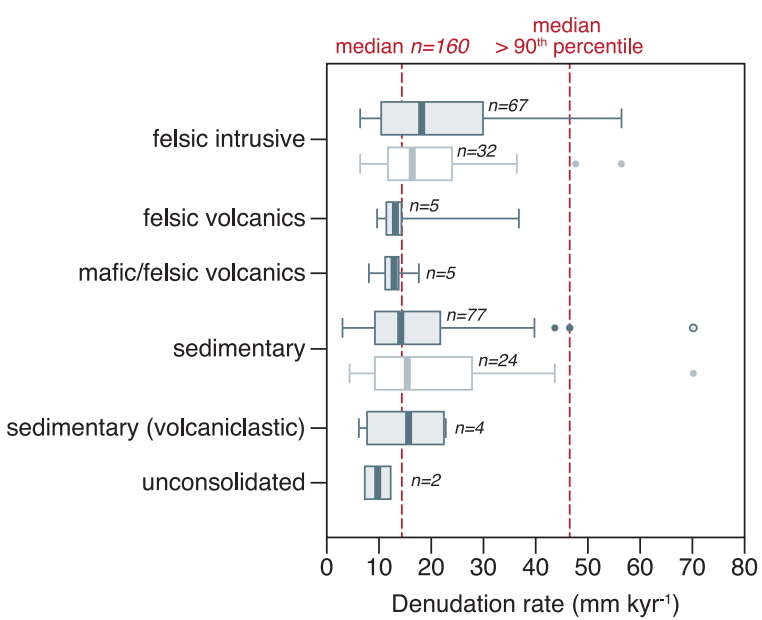

Figure 11: ${ }^{10} \mathrm{Be}$-derived denudation rates grouped by dominant lithology. Dashed vertical lines indicate the median of all denudation rates and the median of denudation rates above the $90^{\text {th }}$ percentile, respectively. White box plots show only data for basins $<150$ $\mathrm{km}^{2}$. Predominant rock-type in each basin was calculated using the Geoscience Australia 1:2.5 million scale Surface Geology of Australia digital dataset [Raymond et al., 2012].

\subsection{Controls on denudation rates: the role of rainfall}

${ }^{10} \mathrm{Be}$-derived denudation rates along the East Australian margin correlate strongly with topographic metrics - especially at the smaller tributary basin scale $\left(R^{2}=0.64-0.71\right.$; Figure 7B), which suggests that topography exerts the main control on rates of landscape lowering in this setting. Denudation rates have been found to strongly correlate with topography globally [e.g., Montgomery \& Brandon 2002; Portenga \& Bierman, 2011; Willenbring et al., 2013] and topography has also been shown to be an important control on denudation rates in other passive continental margin settings [e.g., Codilean et al., 2008; Scharf et al., 2013; Mandal 2015]. Conversely, although strong correlations between ${ }^{10} \mathrm{Be}$-derived denudation rates and rainfall have been observed in some settings [e.g., Moon et al., 2011], most studies report a small to non-existent relationship between the two parameters [e.g., Riebe et al., 2001; Mandal et al., 2015], despite water playing a key role in both the production of sediment (via chemical weathering) and its removal. 
Despite the low correlation coefficients, links between denudation rate and rainfall may still exist, but be difficult to disentangle. For example, the data presented in this study suggest a weak correlation between denudation rate and rainfall along the East Australian margin (Figure $7 \mathrm{~A} 4 \& \mathrm{~B} 4 ; \mathrm{R}^{2}=0.24 / 0.20$ for mainstem basins and $\mathrm{R}^{2}=0.19 / 0.25$ for tributary basins). Yet, as shown in Figure $4 \mathrm{~A}$, most of the highest mainstem ${ }^{10} \mathrm{Be}$ denudation rates are all found in basins that also have the largest rainfall amounts (see also Figure 5, black diamonds), which suggests that in addition to steep slopes and steep channels, rainfall is factor in producing elevated denudation rates. Furthermore, in a recent study, Godard et al. [2019] have compared the regression slopes of ${ }^{10} \mathrm{Be}$ derived denudation rates vs. mean basin slope - taken as a proxy for the efficiency of hillslope denudation - for a range of

620 settings to argue that annual rainfall has an important and non-linear effect on the efficiency of hillslope processes in post-orogenic terrains. Moreover, they used this relationship between regression slope and annual rainfall to suggest that the elevated denudation rates recorded in the Bega section of the East Australian margin (see Figure 4A) are the result of its temperate climate and annual rainfall values falling within a range (1000 $-1500 \mathrm{~mm}$ ) that is optimal for chemical weathering and hillslope erosion. We note, however, that commensurately high denudation rates are recorded in the northernmost basins (e.g., Liverpool and Johnstone), despite annual rainfall in excess of 3,000 $\mathrm{mm}$, value at which Godard et al. [2019] predict denudational processes to be less sensitive to topographic gradients, and thus denudation rates to be potentially lower.

630 Another observation that illustrates the complex links between topography, rainfall, and denudation rates, and further bolsters our suggestion that rainfall exerts an important (albeit secondary) control on denudation rates along the East Australian margin, is the strong relationship that is observed between knickpoint recession distance and basin area. The latter is used as a proxy for discharge (and thus to some extent also a proxy for rainfall) in the stream power formulation of bedrock river incision [Whipple \& Tucker, 1999; Lague, 2014]. In Figure 12, we show knickpoint distance vs. basin area from five of the largest basins east of the continental divide from the southern sector of the margin. These basins feature prominent embayed escarpments located some distance from the continental divide with large-scale knickpoints located at the head of narrow gorges advancing into the upland plateau surface. The data show a strong correlation $\left(R^{2}=0.75\right)$ between the distance 
knickpoints have travelled upstream from the river mouth (i.e., the confluence with the mainstem river for tributary knickpoints) and basin area, also measured at the river mouth. The scatter in Figure 12 can be explained by differences in lithology between the five basins, and given the large basin areas, also by lag time - i.e., the amount of time it takes for the knickpoint in the mainstem river to travel past one tributary on to the next. Thus, knickpoints in tributaries further upstream have had less time to propagate upstream than a knickpoint in a tributary with a similar area but located further downstream in the drainage network. The relationship in Figure 12 is statistically significant, however, and holds across three orders of magnitude basin area, suggesting that the rate of bedrock channel incision is proportional to stream power, and basin area - as a proxy for discharge - and determines the rate at which knickpoints retreat upstream [Whipple \& Tucker, 1999].

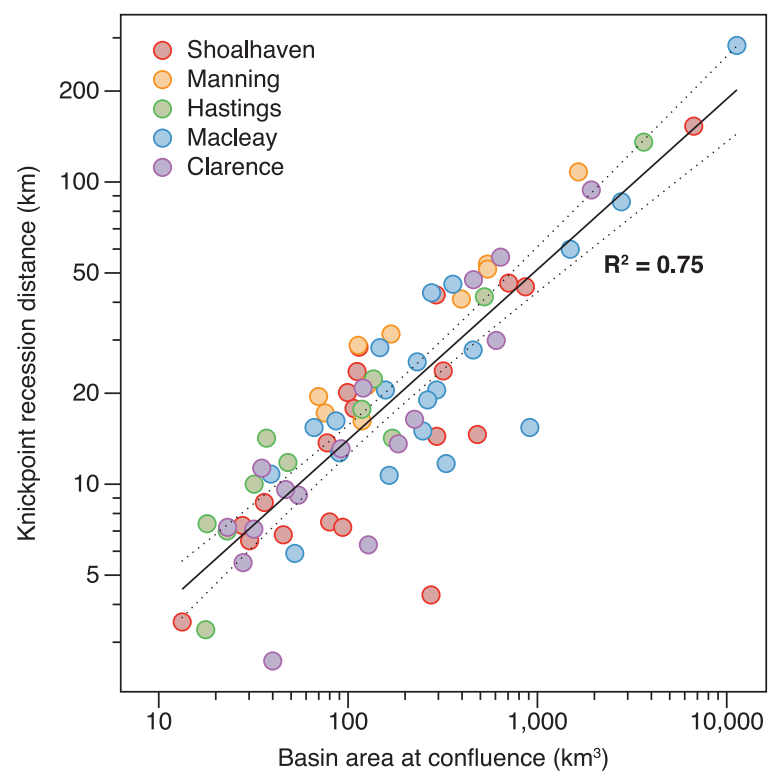

Figure 12: Relationship between knickpoint recession distance measured from confluence and basin area at confluence. Data includes both tributary and mainstem rivers east of the continental divide from five basins characterised by embayed escarpments and large-scale knickpoints along both mainstem and tributary rivers. For mainstem rivers both distance and area are calculated from the outlet defined by the present sea level. Knickpoints were identified based on distance-slope (DS) plots [Goldrick \& Bishop, 2007] using a 30 m SRTM DEM.

The strong positive relationship between distance of knickpoint retreat and basin area shown in Figure 12 is in direct conflict with the findings of Seidl et al. [1996] and Weissel \& 
Seidl [1998] who showed that all of the knickpoints in the Macleay have propagated upstream from the mouth of the mainstem river by about $200 \mathrm{~km}$ and therefore conclude that the distance of knickpoint migration upstream does not depend on basin area (i.e., discharge). Instead of basin area, these authors explain knickpoint propagation inland by slope failure mechanisms and the resulting mass wasting events on the steep rock slope in the knickpoint area. However, relating the location of knickpoints to how far they are from the mouth of the mainstem river is not appropriate. Knickpoint propagation distances should be calculated from the tributary confluence, rather than the mainstem river mouth, as tributary knickpoints are triggered when the base-level signal reaches the confluence and they propagate at a rate that depends on the basin area of the tributary and not on that of the mainstem river [Bishop et al., 2005]. Thus, Seidl et al.'s [1996] and Weissel \& Seidl's [1998] approach was incorrect and resulted in an erroneous conclusion that discharge does not affect knickpoint recession rates in the Macleay.

To summarise, despite the weak correlation between denudation rate and rainfall that is observed in our data, rainfall (when coupled with other topographic variables) can exert control on the rates and styles of landscape lowering in our study area. The role of rainfall in

670 the East Australian setting as opposed to the lack of such a role in other passive margins with a wetter climate, such as, for example, the Western Ghats and Sri Lanka (Figure 10F, black diamonds), might not necessarily be (entirely) due to the East Australian margin's optimal rainfall regime as suggested by Godard et al. [2019]. Rather, it might also be a characteristic feature of the very architecture of arch-type margins [cf. Matmon et al., 2002]. Here, the presence of a prominent escarpment seaward from the continental divide (Figure 1) means that both orographically enhanced rainfall and stream power will be at their maximum at the escarpment zone, promoting the dissection of the highland mass by gorge extension, and so increasing the areal extent of high relief areas that in turn leads to elevated basin averaged denudation rates.

\subsection{Sediment storage and reworking}

Various processes have been identified to explain the cause of ${ }^{26} \mathrm{Al} /{ }^{10} \mathrm{Be}$ ratios in river sediment that plot below the range that is normal for samples experiencing a simple and continuous exposure history (for a complete list of these processes, see Wittmann et al., 
[2020]). Rivers may be tapping older sediment - for example previously buried floodplain material or adjacent older Pleistocene terraces [e.g., Wittmann et al., 2011] or dune sands [e.g., Vermeesch et al., 2010; Eccleshall, 2019] - with depressed ${ }^{26} \mathrm{Al} /{ }^{10} \mathrm{Be}$ ratios being the result of deep burial and decay of both ${ }^{26} \mathrm{Al}$ and ${ }^{10} \mathrm{Be}$. Depressed ${ }^{26} \mathrm{Al} /{ }^{10} \mathrm{Be}$ ratios have also been observed in settings where instead of deep burial, overall sediment fluxes are low and thus rivers continuously rework shallow sediment deposits that are widespread [e.g., Struck et al. 2018a,b, Fülöp et al., 2020]. Here burial is not deep enough to completely stop the production of ${ }^{26} \mathrm{Al}$ and ${ }^{10} \mathrm{Be}$, but both hillslope and fluvial transit times are long enough that even with (or sometimes even in the absence of) shallow burial there is sufficient decay of ${ }^{26} \mathrm{Al}$ and ${ }^{10} \mathrm{Be}$ to detectably alter the $\mathrm{Al} / \mathrm{Be}$ signal. Lastly, in landscapes with low erosion rates $\left(<\approx 1 \mathrm{~mm} \mathrm{kyr} \mathrm{r}^{-1}\right),{ }^{26} \mathrm{Al} /{ }^{10} \mathrm{Be}$ ratios can already be lowered by decay within the bedrock column, and these depressed ratios will then be passed onto river sediment via various erosion pathways [e.g., Struck et al., 2018a; Cazes et al., 2020]. Each of the above processes have been observed in Australian basins and in the case of large systems such as the Lake Eyre and Murray Darling Basins, the depressed ${ }^{26} \mathrm{Al} /{ }^{10} \mathrm{Be}$ ratios observed in their downstream reaches [e.g., Struck et al., 2018b; Eccleshall, 2019] are the result of not one single process, but all of them combined.

As described above, due to the relatively large uncertainties on the measured ${ }^{26} \mathrm{Al} /{ }^{10} \mathrm{Be}$ ratios, only 28 of the 67 samples yield ratios that are lower than the consensus ${ }^{26} \mathrm{Al} /{ }^{10} \mathrm{Be}$ spallation production rate ratio of 6.75 at the $95 \%$ confidence level, and 49 of the 67 samples yield ratios that are lower than 6.75 at the $68 \%$ confidence level (Figure 9). Notwithstanding, all but a few of the 67 samples have ${ }^{26} \mathrm{Al} /{ }^{10} \mathrm{Be}$ ratios that plot below the range that is normal for a simple and continuous exposure history (Figure 8D). In summary, despite the large uncertainties, it is important to note that ${ }^{26} \mathrm{Al} /{ }^{10} \mathrm{Be}$ ratios are consistently lower than what is expected in a setting where sediment experiences a simple history of erosion through the rock column followed by a relatively fast passage through the colluvial and fluvial systems. Our ${ }^{10} \mathrm{Be}$ and ${ }^{26} \mathrm{Al}$ dataset lacks the detail of Struck et al.'s [2018a,b] western Lake Eyre data, and so we cannot fully investigate which compartments (i.e., bedrock, hillslope, fluvial) and which processes are contributing to the depressed ${ }^{26} \mathrm{Al} /{ }^{10} \mathrm{Be}$ ratios. Our basins are significantly smaller than the Murray Darling and Lake Eyre Basins, and so sediment residence times in the fluvial domain will be shorter, however, as illustrated by 
optically stimulated luminescence (OSL) ages from the Lockyer River (Figure 13D; Croke et al. [2016]; Daley et al. [2017]), residence times may still be substantial (10 $10^{3}$ to $10^{5}$ years). Further, unconsolidated valley floor material cover that rivers can potentially rework is widespread in our study area (see Figure 9 A\&B - red diamonds; Figure 13). Hillslope sediment residence times of the order of $200 \mathrm{kyr}$ have also been determined using uraniumseries isotopes for the upper Murrumbidgee basin [Suresh et al., 2014], commensurate with the sediment storage durations that we calculate here (Table S5), suggesting that potential sediment storage times in the colluvial domain might alone be sufficient to explain the depressed ${ }^{26} \mathrm{Al} /{ }^{10} \mathrm{Be}$ ratios observed in our basins. Lastly, a number of small upland plateau basins in our study area record average ${ }^{10}$ Be-derived denudation rates of $\approx 5 \mathrm{~mm} \mathrm{kyr} \mathrm{r}^{-1}$ (Figure 4A), and so we cannot completely rule out the possibility that in some of the basins, depressed ${ }^{26} \mathrm{Al} /{ }^{10} \mathrm{Be}$ ratios might already be inherited from the rock column prior to sediment entering the colluvial and fluvial systems [cf. Struck et al., 2018a].

As noted earlier, the coastal rivers of eastern Australia are hydrologically distinct from the rest of the world, showing a comparatively high flood variability [Finlayson \& McMahon, 1988]. In addition - and as opposed to many other parts of the world where lateral (and regular channel migration) dominates the valley floor sediment storage pattern - the floodplains of east Australia's coastal rivers are dominated by vertical accretion which has occurred since at least the mid Holocene [Nanson \& Young, 1981; Fergusson \& Brierley, 1999a,b; Cohen \& Nanson, 2007]. There is insufficient evidence to state whether this mode of floodplain accumulation in eastern Australia is a function of the narrow and confined settings, the limited sediment supply, the climatic variability, the potential role of Australia's vegetation, or a combination of all of the above. Notwithstanding, vertical accretion combined with high flood variability leads to a cyclical process of periodic floodplain destruction and rebuilding [Nanson, 1986]. Floodplain stripping can be caused by a single 740 large flood, or a series of more moderate floods, that follow a period of quiescence of a few hundred or thousand years over which overbank deposition gradually builds a floodplain.

A salient example of floodplain stripping is the case of the January 2011 catastrophic floods that affected the Brisbane River system in south-east Queensland. The floods, estimated as a 1-in-1000 year event [Thompson \& Croke, 2013], completely removed valley sediment-fills 
on a basin-wide scale in the most confined and upstream reaches of some of the tributaries. In the Lockyer River, a tributary of the Brisbane, the 2011 flood resulted in the total destruction of channel units and the removal of in-channel and riparian vegetation. Along steep headwater streams, 1-3 m of coarse-grained sediment was flushed out, revealing extensive reaches of exposed bedrock channels, and bedrock steps [Baggs Sargood et al. 2015].

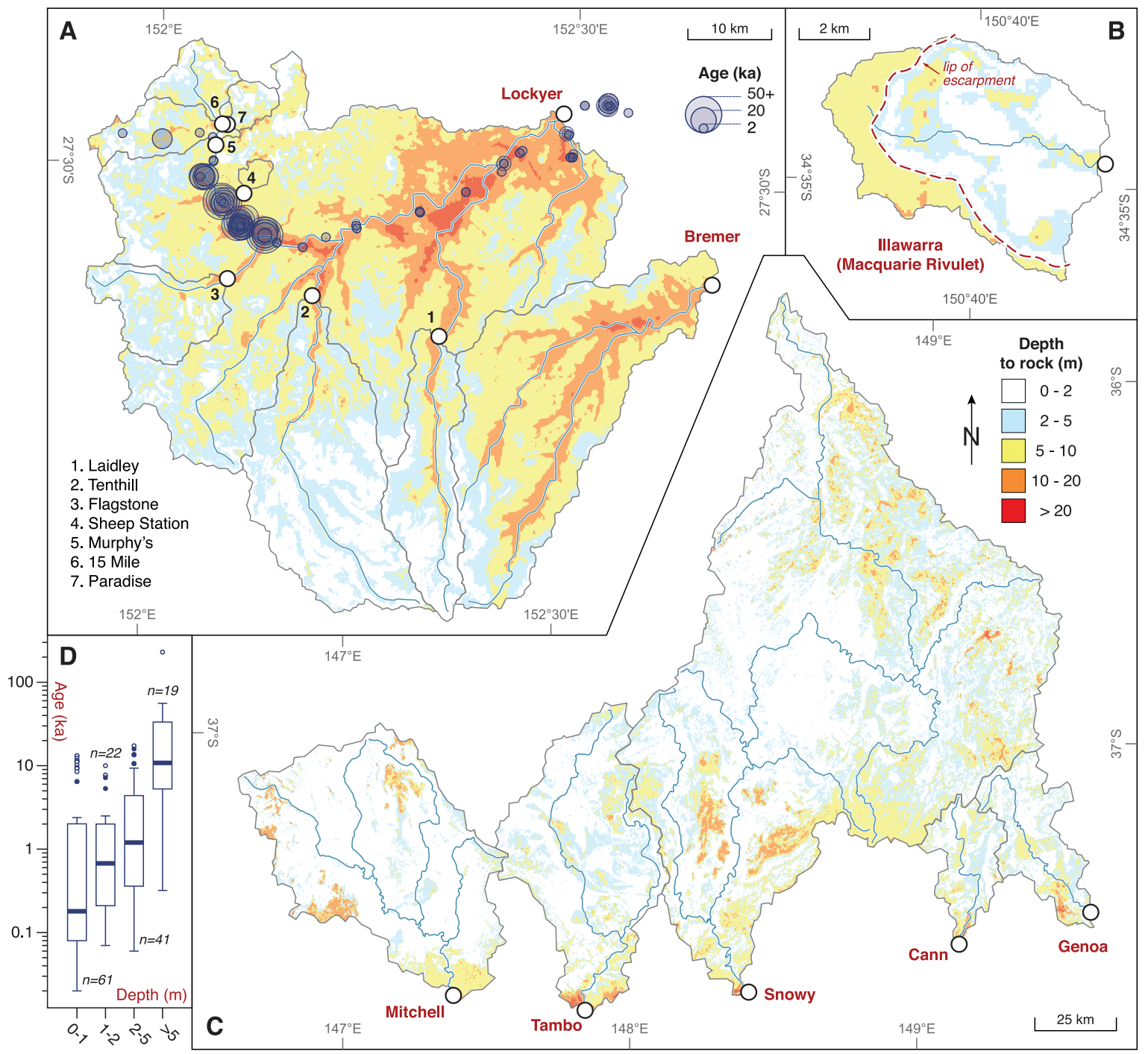

Figure 13: Depth-of-regolith maps for selected basins. (A) to (C) Maps showing the distribution of regolith thickness in basins from south-east Queensland (A), Illawarra (B), and southern Victoria (C) calculated using Wilford et al.'s [2015] depth-of-regolith data. (D) Box plots showing optically stimulated luminescence (OSL) ages of alluvial units vs. their depth from the Lockyer River. Data from Croke et al. [2016] and Daley et al. [2017]. Location of samples and spatial distribution of ages are shown in (A). 
The process of vertical floodplain accretion also promotes rapid and relatively deep burial of sediment, and thus is conducive to loss of cosmogenic radionuclides via decay, and so to lowering of ${ }^{26} \mathrm{Al} /{ }^{10} \mathrm{Be}$ ratios. If storage times are too short for substantial radionuclide decay to occur, at the very least, deep burial within vertically accreted floodplains ensures that the production of ${ }^{10} \mathrm{Be}$ and ${ }^{26} \mathrm{Al}$ ceases and potentially depressed ${ }^{26} \mathrm{Al} /{ }^{10} \mathrm{Be}$ ratios inherited from the bedrock column or hillslope domain are preserved. Moreover, stripping of sediment by large floods, allows rivers to periodically access the deeper, and potentially old, sediment units within floodplains and terraces. For example, as shown in Figure 13, in the upper reaches of the Lockyer River, the median age of alluvial units at depths greater than $5 \mathrm{~m}$ is $\approx 10 \mathrm{ka}$, with the oldest recorded age being $\approx 230 \mathrm{ka}$ [Daley et al., 2017].

Not all east Australian coastal basins have equally high flood variability. However, the basins with the highest flood variability (Figure 9C) broadly correspond to those basins that record the most depressed ${ }^{26} \mathrm{Al} /{ }^{10} \mathrm{Be}$ ratios (Figure $9 \mathrm{~A}$ - solid blue circles). Given the above we propose that there may be a causal link between the hydrological variability that characterises the rivers draining the eastern seaboard of Australia and the non-steady state ${ }^{26} \mathrm{Al} /{ }^{10} \mathrm{Be}$ ratios that we observe in the sediment from these rivers. We posit that sediment residence times in the hillslope domain and the upper reaches of the fluvial network are responsible for the bulk of cosmogenic radionuclide decay, and the periodic stripping of vertically accreted floodplains by large floods means that deeper and potentially older units are periodically incorporated into the sediment mix transported by the modern river.

\subsection{Implications for the long-term evolution of the East Australian margin}

Nott et al. [1996] and Weissel \& Seidl [1998] have documented high rates of gorge extension in the Shoalhaven and Macleay basins, respectively. Using evidence provided by Cenozoic basalts, Nott et al. [1996] estimated a knickpoint retreat rate for the Shoalhaven mainstem of $\approx 2,500 \mathrm{~mm} \mathrm{kyr}^{-1}$ (averaged over $30 \mathrm{Myr}$ ), a value 15 times higher than that inferred using the same basalts for major escarpment retreat in the area $\left(\approx 170 \mathrm{~mm} \mathrm{kyr} \mathrm{r}^{-1}\right)$. Likewise, Weissel \& Seidl [1998] used cosmogenic ${ }^{10} \mathrm{Be}$ and ${ }^{26} \mathrm{Al}$ to show that river incision rates in a tributary of the Macleay are the highest at the gorge head and immediately downstream: incision rates obtained were consistently $>100 \mathrm{~mm} \mathrm{kyr}^{-1}$, in contrast to rates of $\approx 5 \mathrm{~mm} \mathrm{kyr}{ }^{-1}$ recorded upstream of the knickpoint. Our results - namely, the strong 
correlation between denudation rate and topographic metrics - especially channel steepness $\left(k_{\mathrm{sn}}\right)-($ Figure 7B) and the strong correlation between knickpoint recession distance and basin area (Figure 12) - lend further support to these early studies and collectively show that the headward erosion of gorges is an important process in the denudation of the highlands mass and the overall downwearing of the escarpment. As noted earlier, gorge extension results in the dissection of the relatively low-gradient upland plateau surface, increasing the areal extent of high relief areas that in turn leads to elevated basin averaged denudation rates.

Notwithstanding the above, our analysis based on the OCTOPUS database (Figure 10) also suggests that despite rivers driving the dissection of the landscape (via the headward erosion of gorges), there is a 'speed limit' to the overall rate of landscape lowering that is set by the rate at which rock is converted to sediment by chemical weathering [cf. Dixon \& von Blanckenburg, 2012]. Laboratory studies have shown that the sediment load of a bedrock river plays an important role in the fluvial incision process and a decrease in sediment availability will lead to a deficiency in abrasion tools and therefore to a decrease in incision rates [Sklar \& Dietrich, 2001; Turowski et al., 2007]. The link between a lack of tools and decreased rates of incision/denudation has been documented in several post-orogenic settings, where despite steep slopes [e.g., Scharf et al., 2013] or elevated stream power [e.g., Jansen et al., 2011; 2014], overall rates of denudation / incision are very low. As masswasting is not the dominant erosional process, in post-orogenic terrains the availability of sediment in rivers is ultimately controlled by chemical weathering rates [West et al., 2005]. Thus, in these settings, despite the presence of steep slopes and large knickpoints, rates of lowering are substantially slower than those recorded in similar terrains but in a tectonically active setting. Based on the above, we propose that in the context of the East Australian passive margin, while rivers drive the dissection of the landscape, the overall pace of topographic decay is capped by the rate at which the bedrock column is converted to sediment by chemical weathering. The latter provides a mechanism to explain the persistence of transience over million-year timescales and the protracted decay of topographic relief in tectonically passive settings.

\section{Outlook}


Our study identifies major first order controls on ${ }^{10} \mathrm{Be}$-derived denudation rates along the entire length of the East Australian continental margin, explores differences in rates of denudation east and west of the continental divide, and places East Australian denudation rates in a global context by comparing to other high-elevation passive continental margins. We also explore sediment residence times and suggest a link between the flood variability that characterises the coastal rivers of eastern Australia and the ${ }^{26} \mathrm{Al} /{ }^{10} \mathrm{Be}$ ratios recorded in the sediment from these rivers. Our study raises a number of important questions that our data is not suitable to address, however, and we briefly discuss these here.

We posit that while the dissection of the highland mass by gorge extension is a key process in escarpment downwearing along the East Australian margin, overall rates of landscape decay are capped by the rate of chemical weathering occurring on the hillslopes. Testing this assertion, however, requires data on rates of knickpoint retreat. With the exception of a handful of data points from the Shoalhaven River [Nott et al., 1996] and Baker's Creek in the Macleay basin [Weissel \& Seidl, 1998], data on knickpoint retreat rates along the East Australian continental margin are lacking. Cosmogenic ${ }^{10} \mathrm{Be}$ exposure dating of strath terraces flanking the incised channel segments downstream of knickpoints have successfully been used in the past to quantify bedrock incision and knickpoint retreat rates in both tectonically active [Burbank et al., 1996; Leland et al., 1997] and passive settings [Reusser et al., 2004, Jansen et al 2011]. Prominent knickpoints are present in several basins in the 830 southeastern sector of the margin (e.g., Shoalhaven, Macleay, Clarence; see Figure 12) and dating of abandoned strath terraces could be combined with a more detailed sampling of the smaller tributary basins - akin to the approach employed by Godard et al. [2019] in the Bega - to obtain information on basin-wide lowering rates both upstream and downstream of the knickpoints.

Understanding the couplings between hillslopes and channels in our study area also requires information on hillslope sediment pathways and residence times. As shown above (Figure 9), on both sides of the continental divide, in most of the sediment samples, ${ }^{26} \mathrm{Al} /{ }^{10} \mathrm{Be}$ ratios are consistently lower than what is expected in a setting where sediment experience a simple and continuous exposure history. Our ${ }^{26} \mathrm{Al} /{ }^{10} \mathrm{Be}$ data inventory lacks the 840 detail necessary to fully investigate which landscape compartments and which processes are 
responsible for the depressed ${ }^{26} \mathrm{Al} /{ }^{10} \mathrm{Be}$ ratios. Nevertheless, based on independent data from the upper Murrumbidgee basin [Suresh et al., 2014] we propose that residence times in the hillslope domain may be substantial. As demonstrated by Nichols et al. [2005], Jungers et al. [2009], and more recently by Struck et al. [2018a], quantifying sediment residence times in the hillslope domain is possible via detailed sampling of colluvium along longitudinal transects. Introducing a third cosmogenic radionuclide - namely, in-situ produced ${ }^{14} \mathrm{C}$ with a substantially shorter half-life (5730 years) - also reduces the minimum sediment residence times that can be resolved, as demonstrated by Hippe et al. [2012] in the Bolivian Altiplano and by Fülöp et al. [2020] in Australia's Murray-Darling Basin.

850 Lastly, the potential impact of anthropogenic disturbance on ${ }^{10} \mathrm{Be}$-derived denudation rates and ${ }^{26} \mathrm{Al} /{ }^{10} \mathrm{Be}$ ratios is another important issue that requires future study. Long-lived cosmogenic radionuclides such as ${ }^{26} \mathrm{Al}$ and ${ }^{10} \mathrm{Be}$ are insensitive to short-term changes in erosion rates [von Blanckenburg, 2005], and several studies have used ${ }^{10} \mathrm{Be}$ to quantify preanthropogenic denudation rates in landscapes affected by land degradation due to humaninduced land use changes [e.g., Vanacker et al., 2007b; Reusser et al., 2015]. However, the cosmogenic radionuclide inventory of river sediment stops being unaffected by anthropogenic disturbance when the latter is so grave that it results in the exposure of large quantities of deeply shielded material that subsequently get incorporated in the sediment mix exported by rivers.

European settlement of southeastern Australia circa 200 years ago has resulted in massive changes in land use, with the clearing of forests for agriculture and livestock, the drainage of valley bottoms and the clearing of riparian vegetation causing substantial increases in erosion [Cook 2019 and references therein]. Unlike in other regions where human-induced land degradation was mainly focused along cultivated hillslopes [e.g., Trimble, 1974; Montgomery, 2007], in the southeastern Australian Tablelands (and to some extent in other parts of the continental margin), post-settlement sediment fluxes were dominated by material originating from channel incision and bank erosion [Wasson et al., 1998; Olley \& Wasson, 2003; Hughes et al., 2009; Portenga et al., 2017a]. For example, in formerly vegetated headwater systems of the Murrumbidgee (Figure 2) extensive gully networks developed shortly after European settlement, incision leading to confinement of the flow 
and an increase in sediment transport capacity [Olley \& Wasson, 2003]. Channel narrowing and deepening in the upstream reaches was followed by channel widening in the lower reaches, resulting in the widespread deposition of eroded alluvium. This process created a common valley bottom stratigraphy throughout the Tablelands consisting of predisturbance sediments overlain by sandy post-settlement alluvium [Rustomji \& Pietsch, 2007; Portenga et al., 2016]. At present, this common stratigraphy has been exposed in gully walls by further stream incision, and post-settlement alluvium is continuously reworked by the modern streams.

Post-settlement alluvium that originates from a deeply shielded source will have reduced ${ }^{26} \mathrm{Al}$ and ${ }^{10} \mathrm{Be}$ concentrations and potentially also depressed ${ }^{26} \mathrm{Al} /{ }^{10} \mathrm{Be}$ ratios if predisturbance rates of erosion were low (see above). Thus, the incorporation of postsettlement alluvium into the modern sediment flux may result in overestimated ${ }^{10} \mathrm{Be}-$ derived denudation rates and elevated apparent burial ages. Quantifying the effects of postsettlement alluvium reworking on the cosmogenic nuclide inventories exported from basins is possible by comparing ${ }^{26} \mathrm{Al},{ }^{10} \mathrm{Be}$, and ${ }^{14} \mathrm{C}$ abundances and ratios between basins with varying degrees of disturbance or by employing sediment fingerprinting techniques based on meteoric ${ }^{10} \mathrm{Be}$ and bulk sediment optically stimulated luminescence (bulk OSL), that allows gully-derived sediment to be traced back to its source location [e.g., Portenga et al., 2017b].

\section{Conclusions}

We studied the cosmogenic ${ }^{10} \mathrm{Be}(n=160)$ and ${ }^{26} \mathrm{Al}(n=67)$ inventories of sediment from drainage basin along a 3,000 km stretch of Australia's Great Dividing Range between $\approx 38^{\circ} \mathrm{S}$ and $\approx 16^{\circ} \mathrm{S}$ latitude. We sampled 48 drainage basins: 37 draining to the east and discharging into the Tasman and Coral Seas, and 11 draining to the west as part of the larger MurrayDarling and Lake Eyre river systems. Our main conclusions are summarised below.

\footnotetext{
${ }^{10} \mathrm{Be}$-derived denudation rates are overall higher in basins on the eastern side of the continental divide as compared to those on the western side, reflecting differences in topography and to some extent also rainfall. In terms of absolute values, ${ }^{10} \mathrm{Be}$-derived denudation rates range between $7.7 \pm 1.9$ (Mary) and $54.6 \pm 13.7 \mathrm{~mm} \mathrm{kyr}^{-1}$ (North
} 
Johnstone) in mainstem samples and 3.0 \pm 0.7 (Burdekin) and $70.2 \pm 18.9 \mathrm{~mm} \mathrm{kyr}^{-1}$ (Liverpool) in tributary samples to the east of the continental divide. The median denudation rate east of the continental divide is $15.9 \mathrm{~mm} \mathrm{kyr}{ }^{-1}$. On the western side of the divide, denudation rates range between $4.8 \pm 1.2$ (Barcoo) and $15.4 \pm 3.6 \mathrm{~mm} \mathrm{kyr}^{-1}$ (Maranoa) in mainstem samples, and between $4.4 \pm 1.0$ (Murrumbidgee) and $38.5 \pm 7.8 \mathrm{~mm}$ $\mathrm{kyr}^{-1}$ (Murray) in tributary samples. The median denudation rate west of the continental divide is $9.3 \mathrm{~mm} \mathrm{kyr}^{-1}$. The median of all (east and west) denudation rates is $14.5 \mathrm{~mm} \mathrm{kyr}$ and $95 \%$ of denudation rates fall between 5 and $55 \mathrm{~mm} \mathrm{kyr}^{-1}$. These values are virtually identical with those calculated for a global dataset comprising all tectonically passive regions, namely, median $=12.4 \mathrm{~mm} \mathrm{kyr}^{-1}$ and $95 \%$ range of 2 to $65 \mathrm{~mm} \mathrm{kyr}^{-1}$. The similarities

910 are also present when looking at the extreme denudation rate values: the medians of the top $10 \%$ denudation rates recorded here and in other passive margin settings are also similar, despite substantial differences in topography and precipitation between regions. These median denudation rate values are close to the $95^{\text {th }}$ percentile denudation rate for all tectonically passive basins $\left(\approx 53 \mathrm{~mm} \mathrm{kyr}^{-1}\right)$ and are very similar to the global silicate weathering speed limit $\left(\approx 58 \mathrm{~mm} \mathrm{kyr}^{-1}\right)$ calculated as the $95^{\text {th }}$ percentile of global soil weathering rates. The above suggests that in post-orogenic terrain, the overall rates of topographic decay have a speed limit that is imposed by the rate of chemical weathering. Furthermore, given that tectonically quiescent terrains occupy a large proportion of the Earth's continental surface, it can be argued that the relatively low rates at which they are lowering (as compared to those in tectonically active settings), and the protracted timescales of landscape transience that these low rates imply, are the norm globally, rather than the exception. In contrast, tectonically active and / or glacially affected terrains such as Taiwan, New Zealand, Alps, Himalaya record ${ }^{10}$ Be-derived denudation rate above the global $90^{\text {th }}$ percentile for tectonically active regions $\left(\approx 1,000 \mathrm{~mm} \mathrm{kyr}^{-1}\right)$, and so should be perceived as the anomaly instead.

Denudation rates along the East Australian margin correlate strongly with topographic metrics - especially at the smaller tributary basin scale - which suggests that topography exerts the main control on rates of landscape lowering in this setting. Despite lower correlation coefficients, an important link between denudation rate and rainfall is also 930 inferred: most of the highest mainstem ${ }^{10} \mathrm{Be}$ denudation rates all occur in basins which also 
have the highest rainfall amounts and there is a strong correlation between the distance knickpoints have travelled upstream from the river mouth and basin area - a proxy for discharge, and so to some extent also a proxy for rainfall. The links between rainfall and denudation rates in the East Australian setting might be a characteristic feature of the very architecture of the continental margin. Here, the presence of a prominent escarpment seaward from the continental divide means that both orographically enhanced rainfall and stream power will be at their maximum at the escarpment zone, which promotes the dissection of the highland mass by gorge extension, and so increases the areal extent of high relief areas that in turn leads to elevated basin averaged denudation rates. To summarise the above, topographic gradient and to some extent rainfall set the pace of denudation along the East Australian margin, however, these rates are capped by the rate at which rock is converted to sediment by chemical weathering.

On both sides of the divide, in all but a few of the samples, ${ }^{26} \mathrm{Al} /{ }^{10} \mathrm{Be}$ ratios are consistently lower than what is expected in a setting where sediment experience a simple and continuous exposure history. Further, east of the continental divide, the lowest ${ }^{26} \mathrm{Al} /{ }^{10} \mathrm{Be}$ ratios are found in basins that also experience increased flood variability, and we propose that there is a causal link between the hydrological variability that characterises the rivers draining the eastern seaboard of Australia and the non-steady state ${ }^{26} \mathrm{Al} /{ }^{10} \mathrm{Be}$ ratios that we observe in the sediment from these rivers. We posit that sediment residence times in the

950 hillslope domain and the upper reaches of the fluvial network are responsible for the bulk of cosmogenic radionuclide decay, and the periodic stripping of vertically accreted floodplains by large floods means that deeper and potentially older material are periodically incorporated into the sediment mix transported by the modern river. Our study adds to a growing body of recent works that document ${ }^{26} \mathrm{Al} /{ }^{10} \mathrm{Be}$ ratios in tectonically quiescent settings inconsistent with a simple and continuous exposure scenario, suggesting that in these settings non-steady state ${ }^{26} \mathrm{Al} /{ }^{10} \mathrm{Be}$ ratios may be the rule rather than the exception, and sediment pathways from source to sink are complex and transit times protracted. The later has important implications on how we interpret signals of source-area geomorphology from sediment deposited on the shelfs of passive continental margins. 
We thank J. Daley, C. Thompson, T. Furuichi, D. McJannet, K. Hughes, R. Bryan and J. Austin for support with preliminary data analysis and field sample collection, and G.C. Nanson for insightful comments and discussions. We also thank P. Bierman and an anonymous reviewer for comments that improved this work. The analysis shown in Figure 12 was prompted by previous work done by A.T.C. with C. Persano and P. Bishop while at the University of Glasgow. Financial support was provided by the University of Wollongong, the Australian Government's Department of Education and Training (Endeavour Research Fellowship \#5547-2016 to H.M.), and the Centre for Accelerator Science at ANSTO through the National Collaborative Research Infrastructure Strategy (NCRIS). R.B. would like to acknowledge funding support from the CSIRO's Julius Award Program, and sample processing support from S. Tims at the Australian National University. We acknowledge the Traditional Custodians of the lands on which we have worked, and their continued spiritual and cultural connection to Country.

\section{Data Availability}

Data are archived in the supplementary materials. Cosmogenic radionuclide and geospatial data will also be made available via the OCTOPUS database [Codilean et al., 2018].

\section{References}

Abrahams A.D., Cull R.F. (1979) The formation of alluvial landforms along New South Wales coastal streams. Search, v. 10, pp. 187-188.

980 Andrews E.C.F. (1903) Notes on the geography of the Blue Mountains and Sydney district. Proceedings of the Linnean Society of New South Wales, v. 28, pp. 786-825.

Augustinus P., Fink D., Fletcher M.S., Thomas I. (2017) Re-assessment of the mid to late Quaternary glacial and environmental history of the Boco Plain, western Tasmania. Quaternary Science Reviews, v. 160, pp. 31-44.

Baggs Sargood M., Cohen T.J., Thompson C.J., Croke J. (2015) Hitting rock bottom: morphological responses of bedrock-confined streams to a catastrophic flood. Earth Surface Dynamics, v. 3, pp. 265-279.

Balco G., Stone J.O., Lifton N.A., Dunai T.J. (2008) A complete and easily accessible means of calculating surface exposure ages or erosion rates from ${ }^{10} \mathrm{Be}$ and ${ }^{26} \mathrm{Al}$ measurements.

990 Quaternary Geochronology, v. 3, pp. 174-195.

Baldwin J.A., Whipple K.X., Tucker G.E. (2003) Implications of the shear stress river incision model for the timescale of postorogenic decay of topography. Journal of Geophysical Research, v. 108, 2158. 
Barreto H.N., Varajão C.A.C, Braucher R., Bourlès D.L., Salgado A.A.R, Varajão A.F.D.C. (2013) Denudation rates of the Southern Espinhaço Range, Minas Gerais, Brazil, determined by in situ-produced cosmogenic beryllium-10. Geomorphology, v. 191, pp. 1-13.

Barrows T.T., Stone J.O., Fifield L.K., Cresswell R.G. (2001) Late Pleistocene glaciation of the Kosciuszko massif, snowy mountains, Australia. Quaternary Research, v. 55, pp. 179-189.

Barrows T.T., Stone J.O., Fifield L.K., Cresswell R.G. (2002) The timing of the last glacial maximum in Australia. Quaternary Science Reviews, v. 21, pp. 159-173.

Bernard T., Sinclair H.D., Gailleton B., Mudd S.M., Ford M. (2019) Lithological control on the post-orogenic topography and erosion history of the Pyrenees. Earth and Planetary Science Letters, v. 518, pp. 53-66.

Bierman P.R., Caffee M. (2001) Slow rates of rock surface erosion and sediment production across the Namib Desert and Escarpment, Southern Africa. American Journal of Science, v. 301 , pp. $326-358$.

Bierman P.R., Coppersmith R., Hanson K., Neveling J., Portenga E.W., Rood D.H., (2014) A cosmogenic view of erosion, relief generation, and the age of faulting in southern Africa. GSA TODAY, v. 24, pp. 4-11.

1010 Bierman P.R., Steig E.J. (1996) Estimating rates of denudation using cosmogenic isotope abundances in sediment. Earth Surface Processes and Landforms, v. 21, pp. 125-139.

Binnie S.A., Dewald A., Heinze S., Voronina E., Hein A., Wittmann H., von Blanckenburg F., Hetzel R., Christl M., Schaller M., Léanni L., ASTER Team, Hippe K., Vockenhuber C., IvyOchs S., Maden C., Fülöp R.-H., Fink D., Wilcken K.M., Fujioka T., Fabel D., Freeman S.P.H.T., Xu S., Fifield L.K., Akçar N., Spiegel C., Dunai T.J. (2019) Preliminary results of CoQtz-N: A quartz reference material for terrestrial in-situ cosmogenic ${ }^{10} \mathrm{Be}$ and ${ }^{26} \mathrm{Al}$ measurements. Nuclear Instruments and Methods in Physics Research Section B: Beam Interactions with Materials and Atoms, v. 456, pp. 203-212.

Bishop P. (1985) Southeast Australian late Mesozoic and Cenozoic denudation rates: a test for late Tertiary increases in continental denudation. Geology, v. 13, pp. 479-482.

Bishop P. (1988) The eastern highlands of Australia: the evolution of an intraplate highland belt. Progress in Physical Geography, v. 12, pp. 159-182.

Bishop P. (2007) Long-term landscape evolution: linking tectonics and surface processes. Earth Surface Processes and Landforms, v. 32, pp. 329-365.

Bishop P., Goldrick G. (2000) Geomorphological evolution of the East Australian continental margin. In Summerfield M.A. (Ed.), Geomorphology and Global Tectonics. Wiley, Chichester, pp. 227-255.

Bishop P., Goldrick G. (2010) Lithology and the evolution of bedrock rivers in post-orogenic settings: Constraints from the high elevation passive continental margin of SE Australia. In Bishop P., Pillans B. (Ed.), Australian Landscapes. Geological Society, London, Special Publications, v. 346, pp. 267-287.

Bishop P., Hoey T.B., Jansen J.D., Artza I.L. (2005) Knickpoint recession rates and catchment area: the case of uplifted rivers in Eastern Scotland. Earth Surface Processes and Landforms, v. 30, pp. 767-778. 
Bishop P., Young R.W. (1980) Discussion: On the Cainozoic uplift of the southeastern Australian highland. Journal of the Geological Society of Australia, v. 27, pp. 117-119.

Borchers B., Marrero S., Balco G., Caffee M., Goehring B., Lifton N.A., Nishiizumi K., Phillips F., Schaefer J., Stone J.O. (2016) Geological calibration of spallation production rates in the CRONUS-Earth project. Quaternary Geochronology, v. 31, pp. 188-198.

1040 Braucher R., Merchel S., Borgomano J., Bourlès D. (2011) Production of cosmogenic radionuclides at great depth: a multi element approach. Earth and Planetary Science Letters, v. 309, pp. 1-9.

Braun J. (2018) A review of numerical modelling studies of passive margin escarpments leading to a new analytical expression for the rate of escarpment migration velocity. Gondwana Research, v. 53, p. 209-224.

Braun J., Simon-Labric T., Murray K.E., Reiners P.W. (2014) Topographic relief driven by variations in surface rock density. Nature Geoscience, v. 7, pp. 534-540.

Braun J., van der Beek P. (2004) Evolution of passive margin escarpments: what can we learn from low-temperature thermochronology? Journal of Geophysical Research, v. 109,

1050 F04009.

Burbank D.W., Leland J., Fielding E., Anderson R.S., Brozovic N., Reid M.R., Duncan C. (1996) Bedrock incision, rock uplift and threshold hillslopes in the northwestern Himalayas. Nature, v. 378, pp. 505-510.

Bureau of Meteorology (2018). State of the Climate 2018: http://www.bom.gov.au/state-ofthe-climate/State-of-the-Climate-2018.pdf

Cazes G., Fink D., Codilean A.T., Fülöp R.-H., Fujioka T., Wilcken K.M. (2020) ${ }^{26} \mathrm{Al} /{ }^{10} \mathrm{Be}$ ratios reveal the source of river sediments in the Kimberley, NW Australia. Earth Surface Processes and Landforms, v. 45, pp. 424-439.

Child D., Elliot G., Mifsud C., Smith A.M., Fink D. (2000) Sample processing for earth science studies at ANTARES. Nuclear Instruments and Methods in Physics Research Section B: Beam Interactions with Materials and Atoms, v. 172, pp. 856-860.

Cockburn H.A.P., Brown R.W., Summerfield M.A., Seidl M.A. (2000) Quantifying passive margin denudation and landscape development using a combined fission-track thermochronology and cosmogenic isotope analysis approach. Earth and Planetary Science Letters, v. 179, pp. 429-435.

Codilean A.T., (2006) Calculation of the cosmogenic nuclide production topographic shielding scaling factor for large areas using DEMs. Earth Surface Processes and Landforms, v. 31, pp. 785-794.

Codilean A.T., Bishop P., Stuart F.M., Hoey T.B., Fabel D., Freeman S.P.H.T. (2008) Singlegrain cosmogenic ${ }^{21} \mathrm{Ne}$ concentrations in fluvial sediments reveal spatially variable erosion rates. Geology, v. 36, pp. 159-162.

Codilean A.T., Fenton C.R., Fabel D., Bishop P., Xu S. (2014) Discordance between cosmogenic nuclide concentrations in amalgamated sands and individual fluvial pebbles in an arid zone catchment. Quaternary Geochronology, v. 19, pp. 173-180. 
Codilean A.T., Munack H., Cohen T.J., Saktura W.M., Gray A., Mudd S.M. (2018) OCTOPUS: an open cosmogenic isotope and luminescence database. Earth System Science Data, v. 10, pp. 2123-2139.

Cohen T.J., Nanson G.C. (2007) Mind the gap: an absence of valley-fill deposits identifying the Holocene hypsithermal period of enhanced flow regime in southeastern Australia. The Holocene, v. 17, pp. 411-418.

Colwell J.B., Coffin M.F., Spencer R.A. (1993) Structure of the southern New South Wales continental margin, southeastern Australia. BMR Journal of Australian Geology and Geophysics, v. 13, pp. 333-343.

Compo G.P., Whitaker J.S., Sardeshmukh P.D., Matsui N., Allan R.J., Yin X., Gleason B.E., Vose R.S., Rutledge G., Bessemoulin P., Brönnimann S., Brunet M., Crouthamel R.I., Grant A.N., Groisman P.Y., Jones P.D., Kruk M.C., Kruger A.C., Marshall G.J., Maugeri M., Mok H.Y., Nordli O., Ross T.F., Trigo R.M., Wang X.L., Woodruff S.D., Worley S.J. (2011) The Twentieth Century Reanalysis Project. Quarterly Journal of the Royal Meteorological Society, v. 137, pp. 1-28.

1090 Coney P.J., Edwards A., Hine R., Morrison F., Windrim D. (1990) The regional tectonics of the Tasman orogenic system, Eastern Australia. Journal of Structural Geology, v. 12, pp. 519543.

Cook D.E. (2019) Butzer 'Down Under': Debates on anthropogenic erosion in early Colonial Australia. Geomorphology, v. 331, pp. 160-174.

Corbett L., Bierman P., Rood D.H. (2016) An approach for optimizing in situ cosmogenic ${ }^{10} \mathrm{Be}$ sample preparation. Quaternary Geochronology, v. 33, pp. 24-34.

Corbett L., Bierman P., Rood D.H., Caffee M.W., Lifton N.A., Woodruff T.E. (2017) Cosmogenic ${ }^{26} \mathrm{Al} /{ }^{10} \mathrm{Be}$ surface production ratio in Greenland. Geophysical Research Letters, v. 44, pp. 1350-1359.

1100 Craft F.A. (1932) The physiography of the Shoalhaven River Valley. VI. Conclusion. Proceedings of the Linnean Society of New South Wales, v. 57, pp. 245-60.

Craft F.A. (1933) The surface history of Monaro, NSW. Proceedings of the Linnean Society of New South Wales, v. 58, pp. 229-44.

Croke J., Bartley R., Chappell J., Austin J.M., Fifield K., Tims S.G., Thompson C.J., Furuichi T. (2015) ${ }^{10}$ Be-derived denudation rates from the Burdekin catchment: the largest contributor of sediment to the Great Barrier Reef. Geomorphology, v. 241, pp. 122-134.

Croke J., Thompson C.J., Denham R., Haines H., Sharma A., Pietsch T. (2016) Reconstructing a millennial-scale record of flooding in a single valley setting: the 2011 flood-affected Lockyer Valley, south-east Queensland, Australia. Journal of Quaternary Science, v. 31, 1110 pp. 936-952.

Dadson S.J., Hovius N., Chen H., Dade W.B., Hsieh M.L., Willett S.D., Hu J.C., Horng M.J., Chen M.C., Stark C., Lague D., Lin J.C. (2003) Links between erosion, runoff variability and seismicity in the Taiwan orogen. Nature, v. 426, pp. 648-651.

Daley J., Croke J., Thompson C.J., Cohen T.J., Macklin M., Sharma A. (2017) Late Quaternary channel and floodplain formation in a partly confined subtropical river, eastern Australia. 
Journal of Quaternary Science, v. 32, pp. 729-743.

Dixon E., von Blanckenburg F. (2012) Soils as pacemakers and limiters of global silicate weathering. Comptes Rendus - Geoscience, v. 344, pp. 597-609.

Dumitru T.A., Hill K.C., Coyle D.A., Duddy I.R., Foster D.A., Gleadow A.J.W., Green P.F., Kohn 1120 B.P., Laslett G.M., O'Sullivan A.J. (1991) Fission track thermochronology: application to continental rifting of south-eastern Australia. APEA Journal, v. 31 pp. 131-142.

Eccleshall S.V. (2019) The why, when, and where of anabranching rivers in the arid Lake Eyre Basin. Doctor of Philosophy thesis, University of Wollongong, https://ro.uow.edu.au/theses1/554.

Erskine W.D. (1986) River metamorphosis and environmental change in the Macdonald Valley, New South Wales, since 1949. Australian Geographical Studies, v. 24, pp. 80-107.

Falvey D.A., Mutter J.C. (1981) Regional plate tectonics and the evolution of Australia's passive continental margins. BMR Journal of Australian Geology and Geophysics, v. 6, pp. 1-29.

1130 Farr T.G., Rosen P.A., Caro E., Crippen R., Duren R., Hensley S., Kobrick M., Paller M., Rodriguez E., Roth L., Seal D., Shaffer S., Shimada J., Umland J., Werner M., Oskin M., Burbank D., Alsdorf D. (2007) The Shuttle Radar Topography Mission. Reviews of Geophysics, v. 45, RG2004

Ferguson R.J., Brierley G.J. (1999a) Downstream changes in valley confinement as a control on floodplain morphology, lower Tuross River, New South Wales: A constructivist approach to floodplain analysis. In Miller A.J., Gupta A. (Eds.), Varieties of fluvial form. John Wiley \& Sons Ltd, Chichester, pp. 377-407.

Ferguson R.J., Brierley G.J. (1999b) Levee morphology and sedimentology along the lower Tuross River, south-eastern Australia. Sedimentology, v. 46, pp. 627-648.

1140 Fick S.E., Hijmans R.J. (2017) WorldClim 2: new 1km spatial resolution climate surfaces for global land areas. International Journal of Climatology, v. 37, pp: 4302-4315.

Fifield L.K., Tims S.G., Fujioka T., Hoo W.T., Everett S.E. (2010) Accelerator mass spectrometry with the 14UD accelerator at the Australian National University. Nuclear Instruments and Methods in Physics Research Section B: Beam Interactions with Materials and Atoms, v. 268, pp. 858-862.

Finlayson B.L., McMahon T.A. (1988) Australia v. the world: a comparative analysis of streamflow characteristics. In Warner R.F. (Ed.), Fluvial geomorphology of Australia. Academic Press, Sydney, pp. 17-40.

Finnegan N.J., Schumer R., Finnegan S. (2014) A signature of transience in bedrock river 1150 incision rates over timescales of $10^{4}-10^{7}$ years. Nature, v. 505, pp. 391-394.

Forte A.M., Whipple K.X. (2019) Short communication: The Topographic Analysis Kit (TAK) for TopoToolbox. Earth Surface Dynamics, v. 7, pp. 87-95.

Fujioka T., Chappell J. (2010) History of Australian aridity: chronology in the evolution of arid landscapes. In Bishop P., Pillans B. (Ed.), Australian Landscapes. Geological Society, London, Special Publications, v. 346, pp. 121-164. 
Fujioka T., Fink D., Mifsud C. (2015) Towards improvement of aluminium assay in quartz for in situ cosmogenic ${ }^{26} \mathrm{Al}$ analysis at ANSTO. Nuclear Instruments and Methods in Physics Research Section B: Beam Interactions with Materials and Atoms, v. 361, pp. 346-353.

Fülöp R.-H., Codilean A.T., Wilcken K.M., Cohen T.J., Fink D., Smith A.M., Yang B., Levchenko V.A., Wacker L., Marx S.K., Stromsoe N., Fujioka T., Dunai T.J. (2020) Million-year lag times in a post-orogenic sediment conveyor. Science Advances, v. 6, eaaz8845.

Gallagher K., Brown R., Johnson C. (1998) Fission track analysis and its applications to geological problems. Annual Review of Earth and Planetary Sciences, v. 26, pp. 519-572.

Galy V., France-Lanord C., Beyssac O., Faure P., Kudrass H., Palhol F. (2007) Efficient organic carbon burial in the Bengal fan sustained by the Himalayan erosional system. Nature, $v$. 450, pp. 407-411.

Gilchrist A.R., Kooi H., Beaumont C. (1994) Post-Gondwana geomorphic evolution of southwestern Africa - Implications for the controls on landscape development from observations and numerical experiments. Journal of Geophysical Research, v. 99,

$1170 \quad$ pp.12211-12228.

Gilchrist A.R., Summerfield M.A. (1990) Differential denudation and flexural isostasy in formation of rifted-margin upwarps. Nature, v. 346, pp. 739-742.

Gilchrist A.R., Summerfield M.A. (1994) Tectonic models of passive margin evolution and their implications for theories of long-term landscape development. In Kirkby M.J. (Ed.), Process Models and Theoretical Geomorphology. Wiley, Chichester, pp. 55-84.

Godard V., Dosseto A., Fleury J., Bellier O., Siame L., ASTER Team (2019) Transient landscape dynamics across the Southeastern Australian Escarpment. Earth and Planetary Science Letters, v. 506, pp. 397-406.

Goldrick G., Bishop P. (2007) Regional analysis of bedrock stream long profiles: evaluation of 1180 Hack's SL form, and formulation and assessment of an alternative (the DS form). Earth Surface Processes and Landforms, v. 32, pp. 649-671.

Gonzalez V.S., Bierman P.R., Fernandes N.F., Rood D.H. (2016) Long-term background denudation rates of southern and southeastern Brazilian watersheds estimated with cosmogenic ${ }^{10}$ Be. Geomorphology, v. 268, pp. 54-63.

Harel M.A., Mudd S.M., Attal M. (2016) Global analysis of the stream power law parameters based on worldwide ${ }^{10} \mathrm{Be}$ denudation rates. Geomorphology, v. 268, pp. 184-196.

Heimsath A.M., Chappell J., Dietrich W.E., Nishiizumi K., Finkel R.C. (2000) Soil production on a retreating escarpment in southeastern Australia. Geology, v. 28, pp. 787-790.

Heimsath A.M., Chappell J., Dietrich W.E., Nishiizumi K., Finkel R.C. (2001) Late Quaternary 1190 erosion in southeastern Australia: a field example using cosmogenic nuclides. Quaternary International, v. 83, pp. 169-185.

Heimsath A.M., Chappell J., Finkel R.C., Fifield K., Alimanovic A., (2006) Escarpment erosion and landscape evolution in southeastern Australia. In Willett S.D., Hovius N., Brandon, M.T., Fisher D.M. (Eds.), Tectonics, Climate, and Landscape Evolution. Geological Society of America Special Paper 398, Penrose Conference Series, p. 173-190. 
Herman F., Seward D., Valla P.G., Carter A., Kohn B., Willett S.D., Ehlers T.A. (2013)

Worldwide acceleration of mountain erosion under a cooling climate. Nature, v. 504, pp. 423-426.

Hippe K., Kober F., Zeilinger G., Ivy-Ochs S., Maden C., Wacker L., Kubik P.W., Wieler R.

1200 (2012) Quantifying denudation rates and sediment storage on the eastern Altiplano, Bolivia, using cosmogenic ${ }^{10} \mathrm{Be},{ }^{26} \mathrm{Al}$, and in situ ${ }^{14} \mathrm{C}$. Geomorphology, v. 179, pp. 58-70.

Horn B.K.P. (1981) Hill shading and the reflectance map. Proceedings of the IEEE, v. 69, pp. 14-47.

Hughes A.O., Olley J.M., Croke J.C., McKergow L.A. (2009) Sediment source changes over the last 250 years in a dry-tropical catchment, central Queensland, Australia. Geomorphology, v. 104, pp. 262-275.

Jansen J.D., Codilean A.T., Stroeven A.P., Fabel D., Hättestrand C., Kleman J., Harbor J.M., Heyman J., Kubik P.W., Xu S. (2014) Inner gorges cut by subglacial meltwater during Fennoscandian ice sheet decay. Nature Communications, v. 5, 3815.

1210 Jansen J.D., Fabel D., Bishop P., Xu S., Schnabel C., Codilean A.T. (2011) Does decreasing paraglacial sediment supply slow knickpoint retreat? Geology, v. 39, pp. 543-546.

Jenson S.K., Domingue J.O. (1988) Extracting topographic structure from digital elevation data for geographic system analysis. Photogrammetric Engineering and Remote Sensing, v. 54 , pp. $1593-1600$.

Johnson R.W. (1989) Intraplate Volcanism in Eastern Australia and New Zealand. Cambridge University Press, Cambridge.

Jull A.J.T., Scott M.E., Bierman P.R. (1995) The CRONUS-Earth inter-comparison for cosmogenic isotope analysis. Quaternary Geochronology, v. 26, pp. 3-10.

Jungers M.C., Bierman P.R., Matmon A., Nichols K., Larsen J., Finkel R. (2009) Tracing hillslope sediment production and transport with in situ and meteoric ${ }^{10} \mathrm{Be}$. Journal of Geophysical Research: Earth Surface, v. 114, F04020.

Kershaw A.P., Nanson G.C. (1993) The last full glacial cycle in the Australian region. Global and Planetary Change, v. 7, p. 1-9.

Kiem A.S., Franks S.W., Kuczera G. (2003) Multi-decadal variability of flood risk. Geophysical Research Letters, v. 30, 1035.

Kiernan K., Fink D., McConnell A. (2017) Cosmogenic ${ }^{10} \mathrm{Be}$ and ${ }^{26} \mathrm{Al}$ exposure ages of glaciations in the Frankland Range, southwest Tasmania reveal a limited MIS-2 ice advance. Quaternary Science Reviews, v. 157, pp. 141-151.

King L.C. (1959) Denudational and tectonic relief in south-eastern Australia. Transactions of 1230 the Geological Society of South Africa, v. 62, pp. 113-138.

Kohl C.P., Nishiizumi K. (1992) Chemical Isolation of Quartz for Measurement of in-situ produced cosmogenic nuclides. Geochimica et Cosmochimica Acta, v. 56, pp. 3583-3587.

Kooi H., Beaumont C. (1994) Escarpment evolution on high-elevation rifted margins: Insights derived from a surface process model that combines diffusion, advection, and reaction. Journal of Geophysical Research, v. 99, pp. 12191-12210. 
Koppes M.N., Montgomery D.R. (2009) The relative efficacy of fluvial and glacial erosion over modern to orogenic timescales. Nature Geoscience, v. 2, pp. 644-647.

Korup O. (2012) Earth's portfolio of extreme sediment transport events. Earth-Science Reviews, v. 112, pp. 115-125.

1240 Kreemer C., Blewitt G., Klein E.C. (2014) A geodetic plate motion and Global Strain Rate Model. Geochemistry Geophysics Geosystems, v. 15, pp. 3849-3889.

Lague D. (2014) The stream power river incision model: evidence, theory and beyond. Earth Surface Processes and Landforms, v. 39, pp. 38-61.

Lambeck K., Stephenson R. (1986) The post-Palaeozoic uplift history of south-eastern Australia. Australian Journal of Earth Sciences, v. 33. pp. 253-270.

Larsen I.J., Almond P.C., Eger A., Stone J.O., Montgomery D.R., Malcom B. (2014) Rapid soil production and weathering in the Southern Alps, New Zealand. Science, v. 343, pp. 637640.

Leland J., Reid M.R., Burbank D.W., Finkel R., Caffee M. (1998) Incision and differential 1250 bedrock uplift along the Indus River near Nanga Parbat, Pakistan Himalaya, from ${ }^{10} \mathrm{Be}$ and ${ }^{26} \mathrm{Al}$ exposure age dating of bedrock straths. Earth and Planetary Science Letters, v. 154, pp. 93-107.

Lifton N.A., Sato T., Dunai T.J. (2014) Scaling in situ cosmogenic nuclide production rates using analytical approximations to atmospheric cosmic-ray fluxes. Earth and Planetary Science Letters, v. 386, pp. 149-160.

Lister G.S., Etheridge M.A. (1989) Detachment models for uplift and volcanism in the Eastern Highlands, and their application to the origin of passive margin mountains. In Johnson R.W. (Ed.), Intraplate Volcanism in Eastern Australia and New Zealand. Cambridge University Press, Cambridge.

1260 Mandal S.K., Lupker M., Burg J.P., Valla P.G., Haghipour N., Christl M. (2015) Spatial variability of ${ }^{10} \mathrm{Be}$-derived erosion rates across the southern Peninsular Indian escarpment: A key to landscape evolution across passive margins. Earth and Planetary Science Letters, v. 425, pp. 154-167.

Mann P., Gahagan L., Gordon M.B. (2003) Tectonic setting of the world's giant oil and gas fields. In Halbouty M.T. (Ed.), Giant oil and gas fields of the decade 1990-1999. AAPG Memoir 78, pp. 15-105.

Mariotti A., Croke J., Bartley R., Kelley S.E., Fifield L.K., Fülöp R.-H., Codilean A.T., Austin J.M. (2020) Controlling variables of denudation across catchments draining to the Great Barrier Reef, 2020 AGU Fall Meeting 1-17 December, EP036-0002.

1270 Mariotti A., Croke J., Bartley R., Kelley S.E., Ward J.A., Fülöp R.-H., Rood A.H., Rood D.H., Codilean A.T., Wilcken K.M., Fifield L.K. (2021) Pre-development denudation rates for the Great Barrier Reef catchments derived using ${ }^{10} \mathrm{Be}$, Marine Pollution Bulletin, manuscript in review.

Martin H.A. (2006) Cenozoic climatic change and the development of the arid vegetation in Australia. Journal of Arid Environments, v. 66, pp. 533-563. 
Matmon A., Bierman P.R., Enzel Y. (2002) Pattern and tempo of great escarpment erosion. Geology, v. 30, pp. 1135-1138.

Meehl G.A., Boer G.J., Covey C., Latif M., Stouffer R.J. (2000) The Coupled Model Intercomparison Project (CMIP). Bulletin of the American Meteorological Society, v. 81, pp. 313-318.

Miller S.R., Sak P.B., Kirby E., Bierman P.R. (2013) Neogene rejuvenation of central Appalachian topography: Evidence for differential rock uplift from stream profiles and erosion rates. Earth and Planetary Science Letters, v. 369-370, pp. 1-12.

Milliman J.D., Farnsworth K.L. (2011) River Discharge to the Coastal Ocean: A Global Synthesis, Cambridge University Press, Cambridge.

Molnar P., England P. (1990) Late Cenozoic uplift of mountain-ranges and global climate change - chicken or egg. Nature, v. 346, pp. 29-34.

Montgomery D.R. (2007) Is agriculture eroding civilization's foundation? GSA Today, v. 17, pp 4-9.

1290 Montgomery D.R., Balco G., Willett S.D. (2001) Climate, tectonics, and the morphology of the Andes. Geology, v. 29, pp. 579-582.

Montgomery D.R., Brandon M.T. (2002) Topographic controls on erosion rates in tectonically active mountain ranges. Earth and Planetary Science Letters, v. 201, pp. 481489.

Moon S., Chamberlain C.P., Blisniuk K., Levine N., Rood D.H., Hilley G.E. (2011) Climatic control of denudation in the deglaciated landscape of the Washington Cascades. Nature Geoscience, v. 4, pp. 469-473.

Mudd S.M., Harel M.A., Hurst M.D., Grieve S.W., Marrero S.M. (2016) The CAIRN method: automated, reproducible calculation of catchment-averaged denudation rates from cosmogenic nuclide concentrations. Earth Surface Dynamics, v. 4, pp. 655-674.

Nanson G.C. (1986) Episodes of vertical accretion and catastrophic stripping: a model of disequilibrium flood-plain development. Geological Society of America Bulletin, v. 97, pp. 1467-1475.

Nanson G.C., Price D.M., Jones B.G., Maroulis J.C., Coleman M., Bowman H., Cohen T.J., Pietsch T.J., Larsen J.R. (2008) Alluvial evidence for major climate and flow regime changes during the middle and late Quaternary in eastern central Australia. Geomorphology, v. 101, pp. 109-129.

Nanson G.C., Price D.M., Short S.A. (1992) Wetting and drying of Australia over the past 300 ka. Geology, v. 20, p. 791-94.

1310 Nanson G.C., Young R.W. (1981) Overbank deposition and floodplain formation on small coastal streams of New South Wales. Zeitschrift für Geomorphologie, v. 25, pp. 332-347.

Neller R.J. (1980) Channel changes on the Macquarie Rivulet, New South Wales, Zeitschrift für Geomorphologie, v. 24, pp. 168-179.

Nichols K., Bierman P.R., Rood D.H. (2014) ${ }^{10}$ Be constrains the sediment sources and sediment yields to the Great Barrier Reef from the tropical Barron River catchment, 
Queensland, Australia. Geomorphology, v. 224, pp. 102-110.

Nichols K., Bierman P.R., Eppes M.C., Caffee M., Finkel R., Larsen J. (2005) Late Quaternary history of the Chemehuevi Mountain piedmont, Mojave Desert, deciphered using Be-10 and Al-26. American Journal of Science, v. 305, pp. 345-368.

1320 Nishiizumi K. (2004) Preparation of ${ }^{26} \mathrm{Al}$ AMS standards. Nuclear Instruments and Methods in Physics Research Section B: Beam Interactions with Materials and Atoms, v. 223, pp. 388-392.

Nishiizumi K., Imamura M., Caffee M.W., Southon J.R., Finkel R.C., McAninch J. (2007) Absolute calibration of ${ }^{10} \mathrm{Be}$ AMS standards. Nuclear Instruments and Methods in Physics Research Section B: Beam Interactions with Materials and Atoms, v. 258, pp. 403-413.

Nott J., Young R., McDougall I. (1996) Wearing down, wearing back, and gorge extension in the long-term denudation of a highland mass: Quantitative evidence from the Shoalhaven catchment, southeast Australia. Journal of Geology, v. 104, pp. 224-232.

Olley J.M., Wasson R.J. (2003) Changes in the flux of sediment in the Upper Murrumbidgee 1330 catchment, Southeastern Australia, since European settlement. Hydrological Processes, v. 17, pp. 3307-3320.

Ollier C.D. (1982) The Great Escarpment of eastern Australia: tectonic and geomorphic significance. Journal of the Geological Society of Australia, v. 29, pp. 13-23.

Ollier C.D., Pain C.F. (1996) Reply: Landscape evolution and tectonics in southeastern Australia. AGSO Journal of Australian Geology and Geophysics, v. 15, pp. 335-345.

Otto-Bliesner B.L., Marshall S.J., Overpeck J.T., Miller G.H., Hu A., CAPE Last Interglacial Project members (2006) Simulating arctic climate warmth and icefield retreat in the last interglaciation. Science, v. 311, pp. 1751-1753.

Peifer D., Persano C., Hurst M.D., Bishop P., Fabel D. (2020) Growing topography due to contrasting rock types in a tectonically dead landscape. Earth Surface Dynamics Discussion, doi: 10.5194/esurf-2020-68.

Persano C., Stuart F.M., Bishop P., Barfod D. (2002) Apatite (U-Th)/He age constraints on the development of the Great Escarpment on the southeastern Australian passive margin. Earth and Planetary Science Letters, v. 200, pp. 79-90.

Persano C., Stuart F.M., Bishop P., Dempster T. (2005) Deciphering continental breakup in eastern Australia by combining apatite $(\mathrm{U}-\mathrm{Th}) / \mathrm{He}$ and fission track thermochronometers. Journal of Geophysical Research, v. 110, B12405.

Portenga E.W., Bierman P.R. (2011) Understanding Earth's eroding surface with ${ }^{10} \mathrm{Be} . \mathrm{GSA}$ TODAY, v. 21, pp. 4-10.

1350 Portenga E.W., Bishop P., Rood D.H., Bierman P.R. (2017b) Combining bulk sediment OSL and meteoric ${ }^{10} \mathrm{Be}$ fingerprinting techniques to identify gully initiation sites and erosion depths. Journal of Geophysical Research: Earth Surface, v. 122, pp. 513-527.

Portenga E.W., Rood D.H., Bishop P., Bierman P.R. (2016) A late Holocene onset of Aboriginal burning in southeastern Australia. Geology, v. 44, pp. 131-134.

Portenga E.W., Westaway K.E., Bishop P. (2017a) Timing of post-European settlement 
alluvium deposition in SE Australia: A legacy of European land-use in the Goulburn Plains. The Holocene, v. 26, pp. 1472-1485.

Power S., Casey T., Folland C., Colman A., Mehta V. (1999) Inter-decadal modulation of the impact of ENSO on Australia. Climate Dynamics, v. 15, pp. 319-324.

Raymo M.E., Ruddiman W.F. (1992) Tectonic forcing of late Cenozoic climate. Nature, v. 359, pp. 117-122.

Raymond O.L., Gallagher R., Shaw R., Yeates A.N., Doutch H.F., Palfreyman W.D., Blake D.H., Highet L. (2012) Surface Geology of Australia 1:2.5 million scale dataset 2012 edition. Geoscience Australia, Canberra. doi: 10.26186/5c636e559cbe1

Reusser L.J., Bierman P.R., Pavich M.J., Zen E., Larsen J., Finkel R. (2004) Rapid late Pleistocene incision of Atlantic passive-margin river gorges. Science, v. 305, pp. 499-502.

Reusser L.J., Bierman P.R., Rood, D.H. (2015) Quantifying human impacts on rates of erosion and sediment transport at a landscape scale. Geology, v. 43, pp. 171-174.

Riebe C.S., Kirchner J.W., Granger D.E., Finkel R.C. (2001) Minimal climatic control on erosion rates in the Sierra Nevada, California. Geology, v. 29, pp. 447-450.

Rustomji P., Bennett N., Chiew, F. (2009) Flood variability east of Australia's Great Dividing Range. Journal of Hydrology, v. 374, pp. 196-208.

Rustomji P., Pietsch T. (2007) Alluvial sedimentation rates from southeastern Australia indicate post-European settlement landscape recovery. Geomorphology, v. 90, pp. 73-90.

Salgado A.A.R., de Andrade Rezende E., Bourlès D., Braucher R., da Silva J.R., Garcia R.A. (2016) Relief evolution of the Continental Rift of Southeast Brazil revealed by in situproduced ${ }^{10} \mathrm{Be}$ concentrations in river-borne sediments. Journal of South American Earth Sciences, v. 67, pp. 89-99.

Scharf T.E., Codilean A.T., de Wit M., Jansen J.D., Kubik P.W. (2013) Strong rocks sustain ancient postorogenic topography in southern Africa. Geology, v. 41, pp. 331-334.

Schildgen T.F., van der Beek P.A., Sinclair H.D., Thiede R.C. (2018) Spatial correlation bias in late-Cenozoic erosion histories derived from thermochronology. Nature, v. 559, pp. 8993.

Seidl M.A., Weissel J.K. Pratson L.F. (1996) The kinematics and pattern of escarpment retreat across the rifted continental margin of SE Australia. Basin Research, v. 12, pp. 301-316.

Sklar L., Dietrich W.E. (2001) Sediment supply, grain size and rock strength controls on rates of river incision into bedrock. Geology, v. 29, pp. 1087-1090.

Stone J.O. (2000) Air pressure and cosmogenic isotope production. Journal of Geophysical 1390 Research: Solid Earth, v. 105, pp. 23753-23759.

Struck M., Jansen J.D., Fujioka T., Codilean A.T., Fink D., Egholm D.L., Fülöp R.-H., Wilcken K.M., Kotevski S. (2018a) Soil production and transport on postorogenic desert hillslopes quantified with ${ }^{10} \mathrm{Be}$ and ${ }^{26} \mathrm{Al}$. Geological Society of America Bulletin, v. 130, pp. 10171040. 
Struck M., Jansen J.D., Fujioka T., Codilean A.T., Fink D., Fülöp R.-H., Wilcken K.M., Price D.M., Kotevski S., Fifield L.K. (2018b) Tracking the ${ }^{10} \mathrm{Be}-{ }^{26} \mathrm{Al}$ source-area signal in sediment-routing systems of arid central Australia. Earth Surface Dynamics, v. 6, pp. 329349.

Suresh P.O., Dosseto A., Hesse P.P., Handley H.K. (2014) Very long hillslope transport timescales determined from uranium-series isotopes in river sediments from a large, tectonically stable catchment. Geochimica et Cosmochimica Acta, v. 142, pp. 442-457.

Tarboton D.G., Bras R.L., Rodriguez-Iturbe I. (1991) On the extraction of channel networks from digital elevation data. Hydrological Processes, v. 5, pp. 81-100.

Taylor K.E., Stouffer R.J., Meehl G.A. (2012) An Overview of CMIP5 and the experiment design. Bulletin of the American Meteorological Society, v. 93, pp. 485-498.

Thompson C.J., Croke J. (2013) Geomorphic effects, flood power, and channel competence of a catastrophic flood in confined and unconfined reaches of the upper Lockyer valley, southeast Queensland, Australia. Geomorphology, v. 197, pp. 156-169.

Thornbury W.D. (1969) Principles of Geomorphology, 2nd edition. Wiley, New York.

1410 Tomkins K.M., Humphreys G.S., Wilkinson M.T., Fink D., Hesse P.P., Doerr S.H., Shakesby R.A., Wallbrink P.J., Blake W.H. (2007) Contemporary versus long-term denudation along a passive plate margin: the role of extreme events. Earth Surface Processes and Landforms, v. 32, pp. 1013-1031.

Trimble S.W. (1974) Man-induced soil erosion on the Southern Piedmont, 1700-1970. Soil Conservation Society of America, Ankeny, pp. 180.

Tucker G.E., Slingerland R. (1994) Erosional dynamics, flexural isostasy, and long-lived escarpments - a numerical modeling study. Journal of Geophysical Research, v. 99, pp. 12229-12243.

Turowski J.M., Lague D., Hovius N. (2007) Cover effect in bedrock abrasion: A new derivation and its implications for the modelling of bedrock channel morphology. Journal of Geophysical Research, v. 112, F04006.

van der Beek P.A. Braun J. (1999) Controls on post-mid-Cretaceous landscape evolution in the southeastern highlands of Australia: Insights from numerical surface process models. Journal of Geophysical Research, v. 104, pp. 4945-4966.

van der Beek P.A., Braun J. (1998) Numerical modelling of landscape evolution on geological time-scales: A parameter analysis and comparison with the south-eastern highlands of Australia. Basin Research, v. 10, pp. 49-68.

van der Beek P.A., Pulford A., Braun J. (2001) Cenozoic landscape development in the Blue Mountains (SE Australia): Lithological and tectonic controls on rifted margin morphology. Journal of Geology, v. 109, pp. 35-56.

van der Wateren F., Dunai T.J. (2001) Late Neogene passive margin denudation history cosmogenic isotope measurements from the central Namib desert. Global And Planetary Change, v. 30, pp. 271-307.

Vanacker V., von Blanckenburg F., Govers G., Molina A., Poesen J., Deckers J., Kubik P. 
(2007b) Restoring dense vegetation can slow mountain erosion to near natural benchmark levels. Geology, v. 35, pp. 303-306.

Vanacker V., von Blanckenburg F., Hewawasam T., Kubik P.W. (2007a) Constraining landscape development of the Sri Lankan escarpment with cosmogenic nuclides in river sediment. Earth and Planetary Science Letters, v. 253, pp. 402-414.

1440 Veevers J.J. (1984) Phanerozoic Earth History of Australia. Clarendon Press, Oxford.

Veevers J.J. (2000) Billion-year earth history of Australia and neighbours in Gondwanaland. GEMOC Press, Sydney.

Veevers J.J. (2006) Updated Gondwana (Permian-Cretaceous) earth history of Australia. Gondwana Research, v. 9, pp. 231-260.

Vermeesch P. (2007) CosmoCalc: An Excel add-in for cosmogenic nuclide calculations. Geochemistry, Geophysics, Geosystems, v. 8, Q08003.

Vermeesch P., Fenton C.R., Kober F., Wiggs G.F.S., Bristow C.S., Xu S. (2010) Sand residence times of one million years in the Namib Sand Sea from cosmogenic nuclides. Nature Geoscience, v. 3, pp. 862-865.

1450

von Blanckenburg F. (2005) The control mechanisms of erosion and weathering at basin scale from cosmogenic nuclides in river sediment. Earth and Planetary Science Letters, $v$. 237, pp. 462-479.

von Blanckenburg F., Belshaw N., O'Nions R. (1996) Separation of ${ }^{9} \mathrm{Be}$ and cosmogenic ${ }^{10} \mathrm{Be}$ from environmental materials and SIMS isotope dilution analysis. Chemical Geology, v. 129, pp. 93-99.

von Blanckenburg F., Hewawasam T., Kubik P.W. (2004) Cosmogenic nuclide evidence for low weathering and denudation in the wet, tropical highlands of Sri Lanka. Journal of Geophysical Research, v. 109, F03008.

Wasson R.J., Mazari R.K., Starr B., Clifton G. (1998) The recent history of erosion and 1460 sedimentation on the Southern Tablelands of southeastern Australia: sediment flux dominated by channel incision. Geomorphology, v. 24, pp. 291-308.

Weissel J.K., Seidl M.A. (1998) Inland Propagation of Erosional Escarpments and River Profile Evolution Across the Southeast Australian Passive Continental Margin. In Tinkler K.J., Wohl E.E. (Eds.), Rivers Over Rock: Fluvial Processes in Bedrock Channels. AGU Geophysical Monograph Series, v. 107.

Weissel, J.K., Hayes D.E. (1977) Evolution of the Tasman Sea reappraised. Earth and Planetary Science Letters, v. 36, pp. 77-84.

Wellman P. (1979) On the Cainozoic uplift of the southeastern Australian highland. Journal of the Geological Society of Australia, v. 26, pp. 1-9.

1470 Wellman P., McDougall I. (1974) Potassium-Argon ages on the Cainozoic volcanic rocks of New South Wales. Journal of the Geological Society of Australia, v. 21, pp. 247-272.

West A.J., Galy A., Bickle M. (2005) Tectonic and climatic controls on silicate weathering. Earth and Planetary Science Letters, v. 235, pp. 211-228. 
Whipple K.X. (2009) The influence of climate on the tectonic evolution of mountain belts. Nature Geoscience, v. 2, pp. 97-104.

Whipple K.X., Tucker G.E. (1999) Dynamics of the stream-power river incision model: Implications for height limits of mountain ranges, landscape response timescales, and research needs. Journal of Geophysical Research, v. 104, pp. 17661-17674.

Wilcken K.M., Fujioka T., Fink D., Fülöp R.-H., Codilean A.T., Simon K., Mifsud C., Kotevski S. 1480 (2019) SIRIUS Performance: Be-10, Al-26 and Cl-36 measurements at ANSTO. Nuclear Instruments and Methods in Physics Research Section B: Beam Interactions with Materials and Atoms, v. 455, pp. 300-304.

Wilford J., Searle R., Thomas M., Grundy M. (2015) Soil and Landscape Grid National Soil Attribute Maps: Depth of Regolith (3" resolution), Release 2.v6. CSIRO Data Collection. doi: $10.4225 / 08 / 55 C 9472 F 05295$

Wilford J., Searle R., Thomas M., Pagendam D., Grundy M. (2016) A regolith depth map of the Australian continent. Geoderma, v. 266, pp. 1-13.

Willenbring J.K., Codilean A.T., McElroy B. (2013) Earth is (mostly) flat: Apportionment of the flux of continental sediment over millennial time scales. Geology, v. 41, pp. 343-346.

1490 Willenbring J.K., von Blanckenburg F. (2010) Long-term stability of global erosion rates and weathering during late-Cenozoic cooling. Nature, v. 465, pp. 211-214.

Willett S.D. (1999) Orogeny and orography: The effects of erosion on the structure of mountain belts. Journal of Geophysical Research, v. 104, pp. 28957-28981.

Willett S.D., Brandon M.T. (2002) On steady states in mountain belts. Geology, v. 30, pp. 175-178.

Wittmann H., Oelze M., Gaillardet J., Garzanti E., von Blanckenburg F. (2020) A global rate of denudation from cosmogenic nuclides in the Earth's largest rivers. Earth-Science Reviews, v. $204,103147$.

Wittmann H., von Blanckenburg F., Maurice L., Guyot J.L., Kubik P.W. (2011) Recycling of 1500 Amazon floodplain sediment quantified by cosmogenic ${ }^{26} \mathrm{Al}$ and ${ }^{10} \mathrm{Be}$. Geology, v. 39, pp. 467-470.

Young R.W. (1983) The tempo of geomorphological change: evidence from southeastern Australia. Journal of Geology, v. 91, pp. 221-230.

Young R.W., McDougall I. (1993) Long-term landscape evolution: Early Miocene and modern rivers in southern New South Wales, Australia. Journal of Geology, v. 101, pp. 35-49.

Zhang P.Z., Molnar P., Downs W. (2001) Increased sedimentation rates and grain sizes 2-4 Myr ago due to the influence of climate change on erosion rates. Nature, v. 410, pp. 891897. 